\title{
Murine Neonatal Oxidant Lung Injury: NRF2-Dependent Predisposition to Adulthood Respiratory Viral Infection and Protection by Maternal Antioxidant
}

\author{
Hye-Youn Cho ${ }^{1, *}$, Laura Miller-DeGraff ${ }^{1}$, Ligon A. Perrow ${ }^{1}$, Wesley Gladwell ${ }^{1}$, Vijayalakshmi Panduri ${ }^{2}$, \\ Fred B. Lih ${ }^{3}$ and Steven R. Kleeberger ${ }^{1}$ \\ 1 Immunity, Inflammation and Disease Laboratory, National Institute of Environmental Health Sciences, \\ National Institutes of Health, Durham, NC 27709, USA; miller12@niehs.nih.gov (L.M.-D.); \\ perrow@niehs.nih.gov (L.A.P.); gladwell@niehs.nih.gov (W.G.); kleeber1@niehs.nih.gov (S.R.K.) \\ 2 Epigenetic and Stem Cell Biology Laboratory, National Institute of Environmental Health Sciences, \\ National Institutes of Health, Durham, NC 27709, USA; panduriv@niehs.nih.gov \\ 3 Mass Spectrometry Research and Support Group, National Institute of Environmental Health Sciences, \\ National Institutes of Health, Durham, NC 27709, USA; lih@niehs.nih.gov \\ * Correspondence: cho2@niehs.nih.gov; Tel.: +1-984-287-4088
}

Citation: Cho, H.-Y.; MillerDeGraff, L.; Perrow, L.A.; Gladwell, W.; Panduri, V.; Lih, F.B.; Kleeberger, S.R. Murine Neonatal Oxidant Lung Injury: NRF2Dependent Predisposition to Adulthood Respiratory Viral Infection and Protection by Maternal Antioxidant. Antioxidants 2021, 10, 1874. https://doi.org/10.3390/ antiox10121874

Academic Editor: Antonella Casola

Received: 22 October 2021

Accepted: 20 November 2021

Published: 24 November 2021

Publisher's Note: MDPI stays neutral with regard to jurisdictional claims in published maps and institutional affiliations.

Copyright: (c) 2021 by the authors. Licensee MDPI, Basel, Switzerland. This article is an open access article distributed under the terms and conditions of the Creative Commons Attribution (CC BY) license (https:/ / creativecommons.org/licenses/by/ $4.0 /)$.
Abstract: NRF2 protects against oxidant-associated airway disorders via cytoprotective gene induction. To examine if NRF2 is an important determinant of respiratory syncytial virus (RSV) susceptibility after neonate lung injury, $\mathrm{Nrf2}$-deficient $\left(\mathrm{Nrf2}^{-/-}\right)$and wild-type $\left(\mathrm{Nrf2}^{+/+}\right)$mice neonatally exposed to hyperoxia were infected with RSV. To investigate the prenatal antioxidant effect on neonatal oxidative lung injury, time-pregnant $\mathrm{Nrf2}^{-/-}$and $\mathrm{Nrf}^{2^{+/}}$mice were given an oral NRF2 agonist (sulforaphane) on embryonic days 11.5-17.5, and offspring were exposed to hyperoxia. Bronchoalveolar lavage and histopathologic analyses determined lung injury. cDNA microarray analyses were performed on placenta and neonatal lungs. RSV-induced pulmonary inflammation, injury, oxidation, and virus load were heightened in hyperoxia-exposed mice, and injury was more severe in hyperoxia-susceptible $\mathrm{Nrf2}^{-/-}$mice than in $\mathrm{Nrf2}^{+/+}$mice. Maternal sulforaphane significantly alleviated hyperoxic lung injury in both neonate genotypes with more marked attenuation of severe neutrophilia, edema, oxidation, and alveolarization arrest in $\mathrm{Nrf2}^{-/-}$mice. Prenatal sulforaphane altered different genes with similar defensive functions (e.g., inhibition of cell/perinatal death and inflammation, potentiation of angiogenesis/organ development) in both strains, indicating compensatory transcriptome changes in $\mathrm{Nrf2} 2^{-/-}$mice. Conclusively, oxidative injury in underdeveloped lungs NRF2-dependently predisposed RSV susceptibility. In utero sulforaphane intervention suggested NRF2-dependent and -independent pulmonary protection mechanisms against early-life oxidant injury.

Keywords: hyperoxia; bronchopulmonary dysplasia; lung; respiratory syncytial virus; sulforaphane; prenatal; microarray; neonate; mice

\section{Introduction}

Lungs of preterm infants born at 24-36 weeks of gestational age are in the saccular phase of lung development. Extensive developmental changes are represented by widening of distal airways for subsequent formation of alveoli, differentiation of type 1 and 2 alveolar cells, and thinning of the air-blood barrier [1]. Alveolarization in fetal and new-born lungs is critical as the type 2 cells not only produce surfactants but are also involved in innate immunity [2]. In addition, type 1 cells differentiated from type 2 pneumocytes are responsible for barrier function and gas exchange [3]. Bronchopulmonary dysplasia (BPD) is a common outcome of the very low birth weight premature infants who required mechanical ventilation and oxygen therapy for acute respiratory distress. It is one of the most frequent causes of chronic respiratory morbidity in survivors of premature birth $[4,5]$. 
BPD is characterized by failure of alveolarization leading to alveolar simplification and dysmorphic pulmonary vascularization that results from an imbalance between lung injury and lung repair processes, which interrupts normal lung development and leads to diffuse lung fibrosis $[2,6]$. Persistent lung impairment later in life leads to long-term negative pulmonary outcomes and BPD survivors often have functional abnormalities and increased risk for adverse respiratory symptoms (e.g., asthma, bronchiolitis, infectious airway diseases, sleep disorders) as young adolescents and adults [7-10]. Knowledge about BPD pathogenesis has markedly accumulated and advances in neonatal care has improved survival rate in recent years. However, the pathogenesis and molecular mechanisms that lead to lung damage in BPD are not completely understood and there are limited therapeutic options available for prevention and treatment of BPD, which have been only partly satisfactory [8].

Hyperoxia exposure to newborn rodents whose lungs are in the saccular phase has been a model for BPD because their lungs are structurally simplified and functionally affected similar to BPD phenotypes [11,12]. Long-term consequence of neonatally exposed hyperoxia including significantly altered pulmonary function, pulmonary hypertension, and shortened life span were found in rodents [13]. Exposure to early postnatal hyperoxia in mice was also reported to exacerbate cigarette smoke-induced obstructive pulmonary disorder and influenza and rhinovirus infection later in life [14-16].

Nuclear factor, erythroid derived 2, like 2 (NFE2L2, NRF2) is a transcriptional inducer of antioxidant response element (ARE)-bearing host defense genes. Studies with mice genetically deficient in Nrf2 $\left(\mathrm{Nrf2} 2^{-/}\right)$found that NRF2-mediated induction of antioxidants and various cytoprotective genes is essential in mitigation of inflammatory and oxidative airway diseases [17]. Lack of Nrf2 exacerbated hyperoxia-induced BPD-like arrest in alveolarization evidenced by lower radial alveolar count and reduced appearance of multilobular alveoli/branched septi as well as severe exudative-phase diffuse alveolar damage including edema and inflammation in saccular stage lung [18,19]. Sulforaphane (4-methylsulfinylbutyl isothiocyanate, SFN) is a bioactive phytochemical antioxidant and one of its mechanisms is through NRF2 stabilization by inhibition of the cytoplasmic suppressor KEAP1 [20,21]. SFN was determined as a potential drug target that can perturb hyperoxia-induced transcriptome changes in mouse neonates [22]. We recently reported that orally administered SFN lessened hyperoxia-induced lung injury in adult mice in a NRF2-dependent manner [23]. In addition, SFN attenuated airway inflammation and injury against bacterial infection following emphysema, respiratory syncytial virus (RSV), and inhaled arsenic [17,23]. However, overall clinical efficacy of SFN is undetermined [24,25]. Furthermore, little is known about prenatal effects of NRF2 modulation or SFN in postnatal respiratory health.

RSV is a ubiquitous seasonal pathogen that may cause acute lower respiratory tract infection in children and infant hospitalization [26,27]. More recent studies have demonstrated increased risk of severe RSV disease among infants with BPD compared to those with no BPD $[28,29]$. Gestational age is one of the critical risk factors for infant RSV hospitalization rates and appearance of respiratory outcomes [30]. Palivizumab, the humanized RSV monoclonal antibody, has been the only approved option for RSV prophylaxis and it is indicated to reduce RSV-caused serious lower airway infection in high-risk premature infants within six months of the anticipated RSV season [31,32]. NRF2 and antioxidants played a protective role in RSV-induced upper and lower airway disorders and SFN inhibited lung viral replication and neutrophilic inflammation in mice $[33,34]$.

The current study was designed to investigate whether (1) hyperoxia-induced injury in the developmental murine lung affects the later life RSV susceptibility, and (2) maternal supplementation of SFN protects newborn mice against hyperoxic lung injury. We also examined the effect of $\mathrm{Nrf2}$ deficiency in these two models using wild-type $\left(\mathrm{Nrf2^{+/+ }}\right)$ and $N r f 2^{-/-}$mice. 


\section{Materials and Methods}

\subsection{Animals and Time Mating}

Nrf2 $2^{-/-}$(ICR.129P2-Nfe2l2 $\left.{ }^{\text {tm1Mym }}\right)$ and Nrf2 ${ }^{+/+}(\mathrm{Crl}: \mathrm{CD} 1(\mathrm{ICR}))$ mice were generated [19] and maintained in the animal facility at the National Institute of Environmental Health Sciences (NIEHS). $\mathrm{Nrf2}^{+/+}$and $\mathrm{Nrf2}^{-/-}$mice were time mated in the NIEHS animal facility. Time-pregnant foster (Black Swiss) mice were purchased from Taconic Farms, Inc. (Hudson, NY, USA). All animals were housed in a virus- and antigen-free room. Water and mouse chow (modified AIN76A; Harlan Teklad, Madison, WI, USA) were provided ad libitum. All animal use was approved by the NIEHS Animal Care and Use Committee.

\subsection{Gestational SFN Administration and Placenta Collection}

Right lungs Time-pregnant $\mathrm{Nrf2^{+/+ }}$ and $\mathrm{Nrf2^{-/- }}$ mice and time-pregnant foster dams received approximately $9 \mu \mathrm{mol}(1.67 \mathrm{mg}$ ) of pure SFN (R-SFN, LKT Laboratories, Inc., St. Paul, MN, USA) in PBS or vehicle (PBS) by oral gavage (100 $\mu \mathrm{L})$ on embryonic (E) days 11.5, $13.5,15.5$, and 17.5 based on regimens [23,35]. Placenta was collected on E18.5 following the procedure described previously [36]. At E18.5, a subset of $\mathrm{Nrf2}^{+/+}$and $\mathrm{Nrf2} 2^{-/-}$dams were euthanatized by carbon dioxide, the abdominal cavity opened, and the uterus and ovaries were removed intact. The uterus was spread out, extraembryonic membranes (amnion, yolk sac, chorion, allantois) from each embryo were removed and placenta was separated from embryo. The placenta was snap frozen and stored at $-80^{\circ} \mathrm{C}$ for later molecular analysis.

\subsection{Neonate Hyperoxia Exposure}

Two days before scheduled delivery, time-pregnant $\mathrm{Nrf2^{+/+ }}$ and $\mathrm{Nrf2^{-/- }}$ mice were cohabitated with time-pregnant foster dams. Upon birth (PND0), neonatal mice from multiple litters with the same prenatal treatment or same genotype were pooled and randomly reassigned to exposure groups with a foster dam per group. The number of mice per cage was kept at a maximum of 12 and matched between comparison groups to control for the effects of the litter size on nutrition and growth. At $24 \mathrm{~h}$ after birth (PND1), neonatal mice were placed in cages an inserted into an inhalation chamber and exposed to hyperoxia (UHP grade, Min. purity 99.994\% $\mathrm{O}_{2}$, National Welders, Durham, NC, USA) continuously for 2 or 3 days with their foster dams. During exposure, foster dams had free access to food (modified AIN76A; Harlan Teklad) and water. The temperature $\left(72 \pm 3^{\circ} \mathrm{F}\right)$ and humidity $(50 \pm 15 \%)$ of the chamber were monitored, and mice were exposed to a 12-h light-dark cycle. The entire volume of gas in the chamber was flushed via total system flow every 3-4 min to maintain $\mathrm{O}_{2}$ concentration consistent and to avoid $\mathrm{CO}_{2}$ accumulation. Neonatal mice and their foster dams assigned to room air controls were placed in cages placed on a countertop with food and water provided ad libitum for the same exposure duration. The hyperoxia chamber was opened briefly after $24 \mathrm{~h}$ exposure to replace foster dams and to check animal health (morbidity and mortality). For neonate hyperoxia end points in the prenatal SFN study, $\mathrm{Nrf2^{+/+ }}$ and $\mathrm{Nrf2} 2^{-/-}$pups with foster dams were removed from the chamber at the end of 3-day exposure to hyperoxia or room air and pups were euthanized by sodium pentobarbital overdose $(0.02 \mathrm{~mL}$ per neonate). For the adulthood RSV study, $\mathrm{Nrf2}^{+/+}$and $\mathrm{Nrf2}^{-/-}$pups and their foster dams were removed from the chamber and foster dams were replaced after the end of 2-day exposure to hyperoxia or room air. $\mathrm{Nrf2}^{+/+}$ and $N r f 2^{-1-}$ pups with their foster dam were kept in a virus- and antigen-free room. After weaning at PND14, Nrf2 $2^{+/+}$and $\mathrm{Nrf2} 2^{-/-}$mice were housed individually with water and mouse chow (modified AIN76A) until RSV infection at 5 wk of age.

\subsection{RSV Infection}

Neonatal room air- or hyperoxia-exposed mice at $5 \mathrm{wk}$ of age were intranasally (IN) instilled with human RSV19 (ViraSource, Durham, NC, USA; $10^{6}$ plaque forming unit/mouse in $50 \mu \mathrm{L}$ HBSS) or vehicle (Hep-2 cell extracts in $50 \mu \mathrm{L}$ HBSS). After 1 and $5 \mathrm{~d}$ post-IN, mice were euthanized with sodium pentobarbital overdose $(104 \mathrm{mg} / \mathrm{kg})$. 


\subsection{Bronchoalveolar Lavage (BAL) Analyses}

Whole lungs of each neonate from prenatal treatment groups were lavaged in situ, four consecutive times with Hank's balanced salt solution (HBSS, $0.08 \mathrm{~mL} / 2.5 \mathrm{~g}$ body weight) using a 24-gauge BD Angiocath cannula (BD Biosciences, San Diego, CA) as previously described in detail [19]. The pooled BAL fluid returns were centrifuged $(1000 \times g, 10 \mathrm{~min}$ at $\left.4{ }^{\circ} \mathrm{C}\right)$. Aliquots of lavage supernatants $(50 \mu \mathrm{L})$ were analyzed for total protein concentration (a marker of hyperpermeability/edema) in Bradford reagent (Bio-Rad, Hercules, PA, USA) following the manufacturer's procedure. Cell pellets from lavage returns were resuspended in $1 \mathrm{~mL}$ HBSS and $10 \mu \mathrm{L}$ aliquots were counted for total cells using a hemocytometer. Aliquots of cell suspension $(150 \mu \mathrm{L})$ were cytocentrifuged and stained with Wright-Giemsa for differential epithelial and inflammatory cell counts. For young adult mice in RSV study groups, the right lung of each adult mouse was lavaged in situ four consecutive times with HBSS (0.5 mL/25 g b.w.) as indicated elsewhere [37]. Briefly, The BAL fluid returns were centrifuged and an aliquot of the 1st BAL return supernatants $(50 \mu \mathrm{L})$ and aliquots of pooled cell pellet suspension were analyzed for total protein concentration and cell differentials, respectively, as described above. Lactate dehydrogenase (LDH) content was evaluated in aliquots of pooled (neonates, $50 \mu \mathrm{L}$ ) or 1st (adults, $25 \mu \mathrm{L}$ ) BAL return fluids by a colorimetric assay (Sigma-Aldrich, St. Louis, MO, USA) as a cell lysis and cytotoxicity marker.

\subsection{Lung Lipid Oxidation Measurement}

Lung lipid oxidation levels were measured in BAL fluids by estimation of released malondialdehyde (MDA) which forms 1:2 adduct with added thiobarbituric acid (TBA) in acidic condition. Briefly, aliquots of BAL fluid $(75 \mu \mathrm{L})$ were treated with acid reagent $(75 \mu \mathrm{L})$ at room temperature for $15 \mathrm{~min}$ and centrifuged $(14,000 \times \mathrm{g}, 4 \mathrm{~min})$. Supernatants were incubated with TBA reagent at $47^{\circ} \mathrm{C}$ for $2 \mathrm{~h}$. MDA-TBA adducts formation indicated by color changes was determined spectrophotometrically at $532 \mathrm{~nm}$ and pre-incubation absorbance at $532 \mathrm{~nm}$ was subtracted. The amount of MDA in BAL fluids was quantified from a standard curve (TBARS Parameter Assay; R\&D Systems, Minneapolis, MN, USA) that was run in parallel.

\subsection{Sandwich Enzyme-Linked Immunosorbent Assay (ELISA)}

The quantity of chemokine (C-X-C motif) ligand 1 (CXCL1/KC) and interleukin (IL)$1 \beta$ were determined in BAL fluid $(50 \mu \mathrm{L})$ using colorimetric mouse-specific ELISA kits following the manufacturer's instructions (R\&D Systems). To quantify neutrophil abundance in BAL samples ( $25 \mu \mathrm{L})$, neutrophil myeloperoxidase (MPO) level was determined using a mouse specific ELISA kit following the manufacturer's directions (R\&D Systems).

\subsection{Lung Histopathology}

Whole lungs of neonate mice were inflated intratracheally in situ with $10 \%$ neutral buffered formalin (NBF) and the trachea was ligated. The inflated lung was removed from the mouse and fixed in a contained filled with $10 \%$ NBF for 2 days. The fixed left lung was trimmed into two equal sections and tissue blocks were embedded in paraffin and cut into $4 \mu \mathrm{m}$ thickness for hematoxylin and eosin (H\&E) staining. The left lung from each adult mouse was inflated intratracheally in situ with 10\% NBF and fixed following the routine procedure described elsewhere [38]. The fixed lung lobe was cut at proximal (around generation 5) and distal (around generation 11) levels of the main axial airway [39], and paraffin-embedded tissue blocks were cut into $5 \mu \mathrm{m}$-thickness to be stained with H\&E and Masson's trichrome.

\subsection{Serum Immunoglobulin E (IgE) Measurement}

An aliquot of serum $(1 \mu \mathrm{L})$ from each mouse blood sample was collected by cardiac puncture and diluted in an assay diluent (1:100). IgE levels were colorimetically determined 
using a mouse-specific sandwich ELISA kit (BD Opt EIA). Similarly prepared serial dilution of IgE standards (BD Biosciences) were used for IgE quantification.

\subsection{SFN Metabolites Detection in Urine and Milk Bands}

Non-metabolized (unconjugated) SFN and major conjugated metabolites, including SFN-GSH, SFN-cysteine, and SFN-NAC, in mouse urine and milk bands were analyzed by HPLC-mass spectrometry as previously described [23]. That is, an aliquot $(10 \mu \mathrm{L})$ of pooled urine from neonates ( $n=8-13$ /group) and foster dams ( $n=2$ for PBS/Air, $n=$ 2 for SFN/Air) was diluted with $90 \mu \mathrm{L} 5 \%$ methanol and $0.1 \%$ formic acid. The sample was centrifuged at $8{ }^{\circ} \mathrm{C}$ and $80 \mu \mathrm{L}$ of supernatant was transferred to an autosampler vial containing a low volume insert. Milk bands were weighed and homogenized in $300 \mu \mathrm{L}$ of $0.1 \%$ formic acid using a bead mill. A $30 \mathrm{mg}$ of milk homogenate was diluted to $500 \mu \mathrm{L}$ with $0.1 \%$ formic acid and centrifuged at $8{ }^{\circ} \mathrm{C}$. The supernatant was loaded onto Oasis HLB solid phase extraction cartridges. Cartridges were then washed with $1 \mathrm{~mL}$ of $0.1 \%$ formic acid, dried with a stream of nitrogen, washed with $1 \mathrm{~mL}$ hexane to remove neutral lipids, and eluted with $2 \mathrm{~mL}$ of 9:1 acetonitrile:methanol containing 0.1\% formic acid. Eluted milk band samples were dried under vacuum then reconstituted in $50 \mu \mathrm{L} 5 \%$ methanol/0.1\% formic acid. An aliquot $(10 \mu \mathrm{L})$ of prepared urine or milk sample was injected onto an ACE Excel 3 CN-ES $2.1 \times 100 \mathrm{~mm}$ HPLC column with gradient separation at a flow rate of 250 $\mu \mathrm{L} / \mathrm{min}$. Electrospray ionization and selected reaction monitoring mass spectrometry were used for analyte quantitation.

\subsection{Protein Extraction and Detection by Western Blot Analysis}

Right lung or placenta tissues ( $n=3$ /group) were homogenized in RIPA buffer containing PMSF $(10 \mu \mathrm{g} / \mathrm{mL})$ and protease/phosphatase inhibitor cocktail (Sigma-Aldrich, St. Louis, MO, USA) and total proteins were isolated by centrifugation. Snap-frozen neonate lung tissues were pulverized in dry ice (two pooled sample/group, four lungs/sample) for nuclear proteins isolation using a kit following the manufacturer's direction (Active Motif, Carlsbad, CA, USA). Quantified proteins were aliquoted and stored at $-80{ }^{\circ} \mathrm{C}$ until used. Lung nuclear $(7 \mu \mathrm{g})$ or pooled total placenta $(50 \mu \mathrm{g})$ proteins were subjected to Western blotting using antibodies against mouse c-Fos (Santa Cruz Biotechnology, Inc., Dallas, TX, USA), lamin B (Santa Cruz, Dallas, TX, USA), phosphor-p42/p44 mitogen-activated protein kinase/extracellular signal-regulated kinase ( $P$-p42/p44 MAPK/P-ERK, Santa Cruz) and pan-actin (Santa Cruz). The assay was done in duplicate and scanned band images were quantitated by densitometry using Image J Gel Analysis software and relative protein band intensities normalize to PBS/air-Nrf2 $2^{+/+}$(lung c-Fos) or PBS-Nrf2 ${ }^{+/+}$(placenta P-ERK) were depicted.

\subsection{Protein Oxidation Detection}

Protein carbonyl groups introduced into protein side chains by oxidative reactions were quantified in lung total protein aliquots by a colorimetric analysis. Briefly, an aliquot of total lung protein $(1 \mu \mathrm{g}$ in $100 \mu \mathrm{L}$ volume $)$ and oxidized/reduced BSA standards were adsorbed onto a 96-well plate (OxiSelect Protein Carbonyl ELISA kit; Cell Biolabs, Inc., San Diego, CA, USA) overnight at $4{ }^{\circ} \mathrm{C}$, and protein carbonyls were derivatized by $2.4-$ dinitrophenyl hydrazine (DNPH). The DNPH-derivatized protein samples were then incubated with an anti-DNP antibody and an HRP-conjugated secondary antibody in turn following the manufacturer's instructions. The protein carbonyl contents indicating oxidated protein level were determined by colorimetric analysis at $450 \mathrm{~nm}$ using a reduced and oxidized BSA standard curve.

\subsection{Nuclear DNA Binding Assay}

Nuclear factor kappa-light-chain-enhancer of activated B cells (NF-kB) P65-DNA binding activity was quantitated using a transcription factor binding assay kit (Abcam, Cambridge, MA, USA). Briefly, nuclear protein aliquots ( $2 \mu \mathrm{g}$, duplicates) were added to 
ELISA plate wells coated with NF- $\kappa$ B consensus dsDNA sequence and incubated overnight at $4{ }^{\circ} \mathrm{C}$. The wells were then washed and added with NF- $\kappa \mathrm{B}$ p65 primary antibody for incubation. After consecutive incubation with secondary antibody and detection reagent, colorimetric analysis at $450 \mathrm{~nm}$ determined DNA-bound NF-kB p65 amount.

\subsection{Lung DNA Damage Measurement}

Quantitative polymerase chain reaction (PCR) was used to determine the presence of genomic or mitochondrial DNA lesions (including base modifications, AP sites, and strand breaks) which blocks the progression of DNA polymerase so that only undamaged templates can be amplified [40]. Briefly, total cellular DNA was isolated from frozen lungs using a kit (Qiagen Inc., Valencia, CA, USA), and a fragment of DNA from either nuclei (6.5 kb of DNA polymerase $\beta$ ) or mitochondria (117-bp fragment and 10-kb fragment) were amplified in ABI Prism 7700 Sequence Detection System (Applied Biosystems by Life Technologies, Foster City, CA, USA) using specific primer sets [19]. The amount of DNA amplification is inversely proportional to the amount of DNA damage such that increasing damage causes a decrease in amplification $(1,10)$. Amplification (as determined by picogreen fluorescence) of hyperoxia-treated samples was compared with that of undamaged controls to calculate the relative amplification. Relative amplification values were then used to calculate the average number of lesions per $10 \mathrm{~kb}$ of the genomic or mitochondrial DNA, using a Poisson distribution. The amount of damage is presented as ln (mean of hyperoxia amplification/mean of the control samples). The amount of long mitochondrial amplification product $(10 \mathrm{~kb})$ was normalized to the mitochondrial DNA copy number using the small 117-bp fragment.

\subsection{Lung RNA Isolation and Reverse Transcriptase-Polymerase Chain Reaction (RT-PCR)}

Total RNA was isolated from left lung or placenta homogenates (RNeasy Mini Kit, Qiagen Inc., Dusseldorf, Germany). One $\mu \mathrm{g}$ of RNA was reverse transcribed into cDNAs using GeneAmp PCR System 9700 (Applied Biosystems) and an aliquot of cDNA (40 ng) was added to the reaction for semi-quantitative PCR (1 kb Nrf2 amplicon) as previously described [33] or quantitative PCR in $25 \mu \mathrm{L}$ reaction containing $12.5 \mu \mathrm{L} 2$ X Power SYBR Green Master Mix (Applied Biosystems, Foster City, CA, USA) and 240 nM of customdesigned [41] or commercially available (Real Time Primers, LLC, Elkins Park, PA, USA) primers for mouse Nrf2, glutamate-cysteine ligase catalytic subunit (Gclc), glutathione-stransferase P1 (Gstp1), Gstt1, NAD(P)H quinone dehydrogenase (quinone) 1 (Nqo1), ADAM like decysin 1 (Adamdec1), and ubiquitin C-terminal hydrolase L1 (Uchl1) by 10 min hold at $95^{\circ} \mathrm{C}$ and up to 45 cycles of $95^{\circ} \mathrm{C}(15 \mathrm{~s})-60{ }^{\circ} \mathrm{C}(1 \mathrm{~min})$ using an ABI Prism 7700 Sequence Detection System (Applied Biosystems) or CFX Connect Realtime System (Bio-Rad). The target gene expression was calculated using the comparative threshold cycle $\left(\mathrm{C}_{\mathrm{T}}\right)$ method from the fluorescence detected $C_{T}$ difference between $18 \mathrm{~s}$ rRNA and target gene $\left(\Delta C_{T}\right)$ in the same sample.

\subsection{6. cDNA Microarray Analyses}

Total lung RNA (100 ng, $n=3$ /group) from placenta (E18.5) or neonate lung (PND4) was applied to mouse 4302.0 arrays (Affymetrix, Inc., Santa Clara, CA, USA) in the NIEHS Microarray Core Facility as described previously [19]. Array data were analyzed statistically using GeneSpring software (Agilent Technologies, Inc., Santa Clara, CA, USA). Briefly, array raw data were filtered by lower expression percentile (at least 1 sample had values within $20 \%$ cut-off rage) and the expression levels were normalized to the mean value of the experimental control (lung-PBS/ Air $/ \mathrm{Nrf2}^{+/+}$, placenta-PBS/Nrf2 ${ }^{+/+}$) for each gene by quantile algorithm. Student's $t$-test (PBS vs. SFN in each genotype for placenta or lung) or two-way ANOVA (PBS vs SFN and air vs. hyperoxia in each genotype lung) identified differentially expressed genes in $\mathrm{Nrf2^{+/+ }}$ or in $\mathrm{Nrf2} 2^{-/-}$mice using GeneSpring (Agilent Technologies, Inc., Santa Clara, CA, USA). Overlapping or unique genes in both genotypes were determined by Venn Diagram analyses. Potential 
molecular interactions, biological functions, downstream and upstream pathways were determined by Ingenuity Pathway Analysis (IPA, Qiagen). Microarray data are deposited in Gene Expression Omnibus (accession numbers: GSE164699 for the neonate lungs and GSE164700 for the placenta).

\subsection{Statistics}

Data are presented as the group mean \pm standard error of the mean (S.E.M.). The effects of neonate inhalation exposure/adulthood intranasal treatment (air/vehicle, air/RSV, $\mathrm{O}_{2}$ /vehicle, or $\left.\mathrm{O}_{2} / \mathrm{RSV}\right)$ and genotype $\left(\mathrm{Nrf2}^{+/+}, \mathrm{Nrf2} 2^{-/-}\right)$in adulthood RSV study or the effects of prenatal treatment/neonate exposure (PBS/air, $\mathrm{PBS} / \mathrm{O}_{2}, \mathrm{SFN} /$ air, $\mathrm{SFN} / \mathrm{O}_{2}$ ) and genotype $\left(\mathrm{Nrf2} 2^{+/+}, \mathrm{Nrf2} 2^{-/}\right)$in gestational SFN study was evaluated by two-way ANOVA. Nrf2 mRNA assessment in Nrf2 $2^{+/+}$mice was done by One-way ANOVA. Student-NewmanKeuls test was used for a posteriori comparisons of means $(p<0.05)$. SigmaPlot 13.0 or 14.0 package (Systat Software, San Jose, CA, USA) was used for all statistical analyses.

\section{Results}

\subsection{Effect of Neonatal Hyperoxia on Adulthood RSV Pathogenesis}

\subsubsection{NRF2-Dependent Augmentation of Lung Inflammation and Injury}

Significantly greater RSV-induced neutrophilic inflammation ( $1 \mathrm{~d}$ post-IN) was found in $N r f 2^{-/}$mice neonatally exposed to $\mathrm{O}_{2}$ than in those neonatally exposed to air, and the heightened neutrophilic infiltration was remained elevated in neonatal $\mathrm{O}_{2}$-exposed Nrf2 $2^{-/}$mice at $5 \mathrm{~d}$ (Figure 1A). Vehicle treatment also caused significant increase of neutrophils in neonatal air- or $\mathrm{O}_{2}$-exposed $\mathrm{Nrf2} 2^{-/-}$mice (Figure $1 \mathrm{~A}$ ). In $\mathrm{Nrf2} 2^{+/+}$mice, there was no significant additive effect of neonatal $\mathrm{O}_{2}$ exposure in $\mathrm{RSV}$-induced neutrophilic inflammation (Figure 1A). RSV infection caused significant lymphocyte infiltration in $\mathrm{Nrf2} 2^{-/-}$mice among mice pre-exposed to air at $1 \mathrm{~d}$ (Figure $1 \mathrm{~B}$ ). Neonatal $\mathrm{O}_{2}$ exposure significantly potentiated lymphocytic inflammation in both $\mathrm{Nrf2} 2^{+/+}$and $\mathrm{Nrf2} 2^{-/-}$mice after either vehicle or RSV at $1 \mathrm{~d}$ (Figure 1B). RSV-induced lymphocytic inflammation remained elevated by $5 \mathrm{~d}$ in $\mathrm{Nrf2} 2^{-/-}$mice exposed to either air or $\mathrm{O}_{2}$, while there was no significant exacerbation of lymphocytic infiltration by previous $\mathrm{O}_{2}$ exposure in either genotype of mice at this time (Figure 1B). Significant RSV-induced epithelial cell sloughing was found in neonatal air-exposed $N r f 2^{+/+}(5 \mathrm{~d})$ and $N r f 2^{-/-}(1$ and $5 \mathrm{~d})$ mice (Figure $\left.1 \mathrm{C}\right)$. BAL epithelial cell number was significantly abundant in $\mathrm{Nrf2} 2^{-/-}$mice than in $\mathrm{Nrf2^{+/+ }}$ mice either exposed to prenatal air or $\mathrm{O}_{2}$ and RSV-induced epithelial injury was exacerbated by neonatally exposed $\mathrm{O}_{2}$ in $\mathrm{Nrf2} 2^{+/+}$mice at $1 \mathrm{~d}$ (Figure 1C). Consistent with neutrophil numbers, neutrophil chemoattractant CXCL1 level at $1 \mathrm{~d}$ was significantly increased by neonate $\mathrm{O}_{2}$ relative to neonate air in both genotypes while the augmentation by $\mathrm{O}_{2}$ was more significant in $N r f 2^{-/-}$mice than in $N r f 2^{+/+}$mice (Figure 1D). Proinflammatory cytokine IL- $1 \beta$ contents in BAL were also significantly greater in $\mathrm{O}_{2} / \mathrm{RSV}-\mathrm{Nrf2} 2^{-/-}$mice compared to $\mathrm{O}_{2} / \mathrm{RSV}-\mathrm{Nrf2} 2^{+/+}$mice at $1 \mathrm{~d}$ (Figure 1D). BAL LDH levels reflected significantly enhanced lung tissue damage and epithelial cell death in neonatal $\mathrm{O}_{2}$-exposed, RSV-infected $\mathrm{Nrf2} 2^{-/-}$ mice (Figure 1D).

\subsubsection{NRF2-Dependent Augmentation of Lung Histopathology}

H\&E (Figure 2A) and Masson's trichrome (Figure 2B) staining showed that RSV infection caused more severe alveolar inflammation and small bronchial smooth muscle thickening in neonatal air-exposed $N r f 2^{-/-}$mice (Figure $2 \mathrm{~A}(\mathrm{f}), \mathrm{B}(\mathrm{n})$ ) than in neonatal airexposed $\mathrm{Nrf2}^{+/+}$mice at $1 \mathrm{~d}$ post-IN (Figure $\left.2 \mathrm{~A}(\mathrm{~b}), \mathrm{B}(\mathrm{j})\right)$. Neonatal $\mathrm{O}_{2}$ exposure augmented airway inflammatory cell accumulation and bronchial smooth muscle thickening in both strains but more severely in $N r f 2^{-/-}$mice (Figure $2 \mathrm{~A}(\mathrm{~h}), \mathrm{B}(\mathrm{p})$ ) than in $N r f 2^{+/+}$mice (Figure $2 \mathrm{~A}(\mathrm{~d}), \mathrm{B}(\mathrm{l}))$. Slightly thickened alveolar septum, alveolar vacuolization, and moderate alveolar and perivascular-peribronchiolar fibroproliferation with collagen accumulation (Figure $2 \mathrm{~A}(\mathrm{c}), \mathrm{B}(\mathrm{k})$ ) were found in $\mathrm{O}_{2} /$ vehicle-Nrf2 ${ }^{+/+}$mice compared to air/vehicle-Nrf2 $2^{+/+}$ mice (Figure $2 \mathrm{~A}(\mathrm{a}), \mathrm{B}(\mathrm{i})$ ). These histologic features in $\mathrm{O}_{2} /$ vehicle-Nrf2 $2^{+/+}$mice were more 
predominant in $\mathrm{O}_{2} /$ vehicle-Nrf2 ${ }^{-/-}$mice (Figure $2 \mathrm{~A}(\mathrm{~g}), \mathrm{B}(\mathrm{o})$ ). RSV-induced exacerbation of collagen accumulation in alveoli as well as perivascular-peribronchiolar region was marked in $\mathrm{O}_{2} / \mathrm{RSV}_{-N} r f 2^{-/-}$mice at $5 \mathrm{~d}$ post-IN (Figure $2 \mathrm{~B}(\mathrm{p})$ ).

A

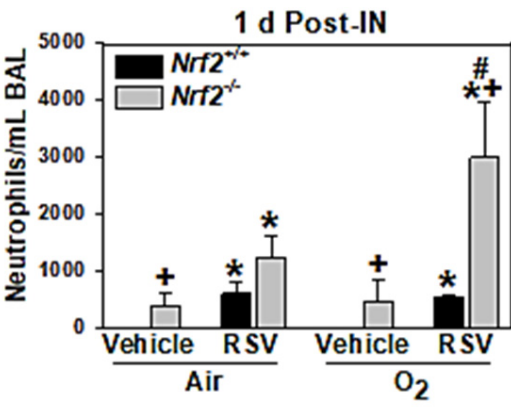

B

C
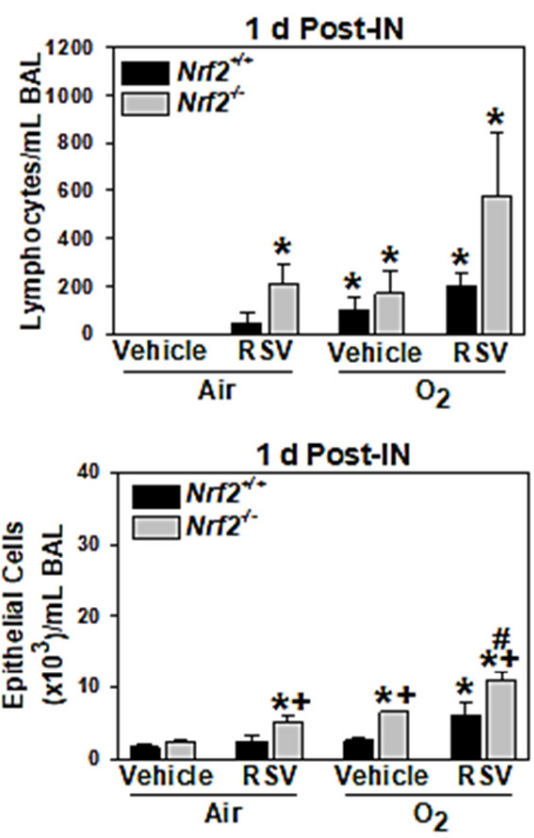
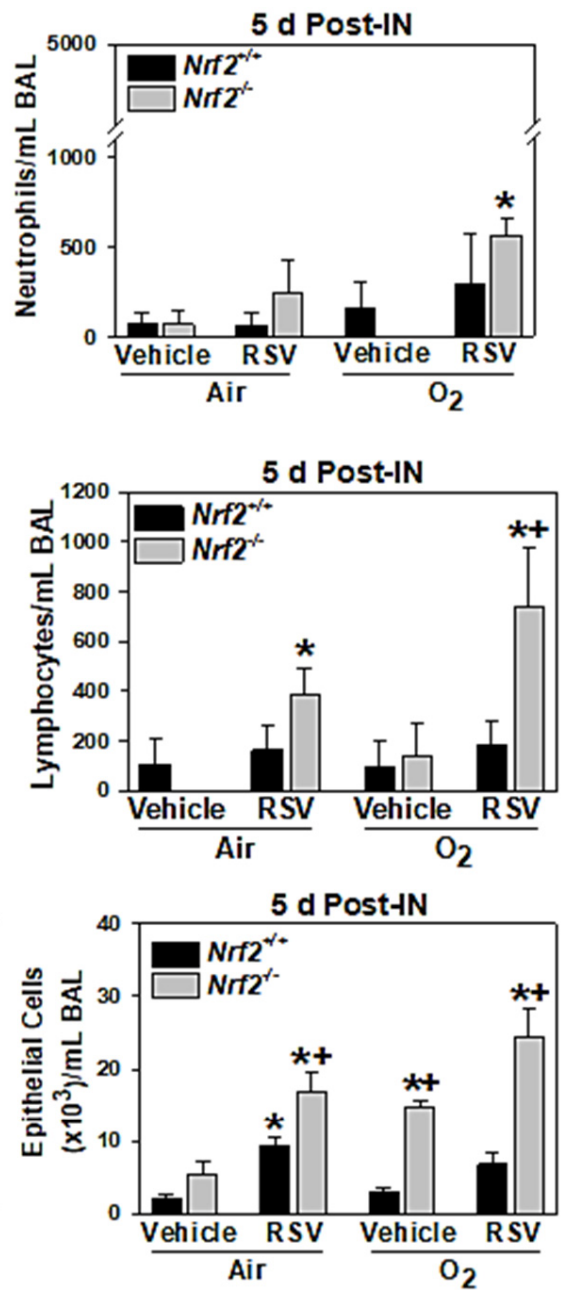

D
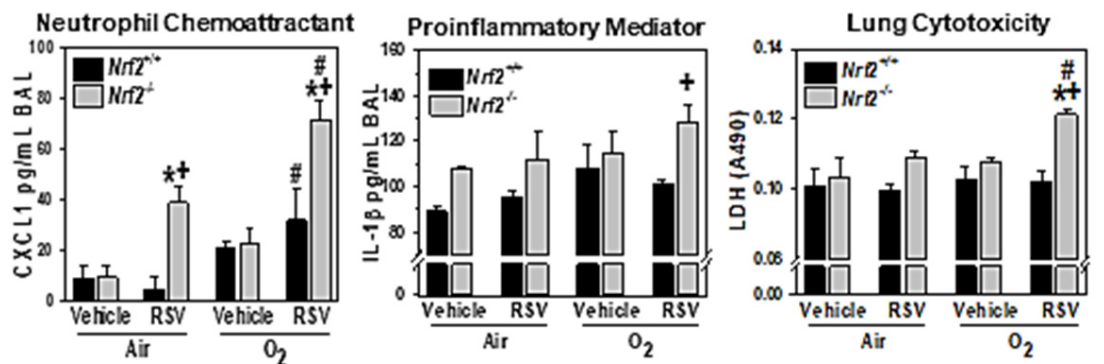

Figure 1. Differential lung inflammation and injury in response to respiratory syncytial virus (RSV) infection following neonatal hyperoxia $\left(\mathrm{O}_{2}\right)$ exposure in wild-type $\left(\mathrm{Nrf2}^{+/+}\right)$and $\mathrm{Nrf2}$-deficient $\left(\mathrm{Nrf2^{-/ }}\right)$ mice. Lung injury phenotypes were assessed by the number of neutrophils (A), lymphocytes (B), and epithelial cells (C) in bronchoalveolar lavage (BAL) fluids at $1 \mathrm{~d}$ and $5 \mathrm{~d}$ post-intranasal (IN) instillation of vehicle or RSV. Data presented as group mean \pm S.E.M ( $n=3-5$ /group). (D) A neutrophil chemoattractant, chemokine (C-X-C motif) ligand 1 (CXCL1), a proinflammatory mediator interleukin (IL)- $1 \beta$, and a lung injury and cytotoxicity marker lactate dehydrogenase (LDH) were determined in BAL fluids at $1 \mathrm{~d}$ post-IN. Group mean \pm S.E.M. $\left(n=3-4\right.$ /group) presented. ${ }^{*}$, significantly different from genotype-matched air/vehicle controls $(p<0.05) .+$, significantly different from exposure/intranasal treatment matched $\mathrm{Nrf} 2^{+/+}$mice $(p<0.05)$. \#, significantly different from genotype-matched, intranasal treatment-matched air $(p<0.05)$. 


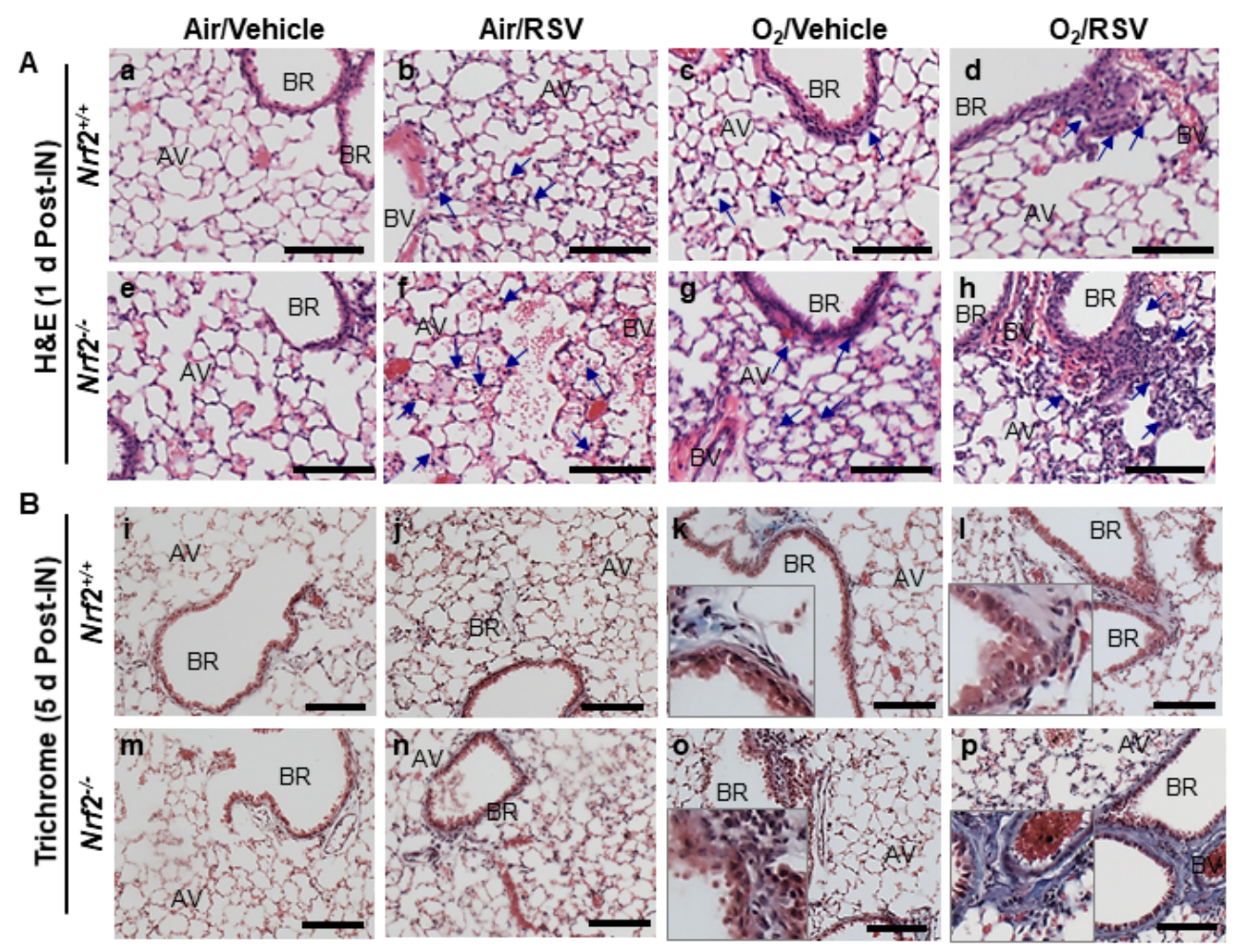

Figure 2. Differential pulmonary histopathology after respiratory syncytial virus (RSV) infection following neonatal hyperoxia $\left(\mathrm{O}_{2}\right)$ exposure in wild-type $\left(\mathrm{Nrf2}^{+/+}\right)$and $\mathrm{Nrf2}$-deficient $\left(\mathrm{Nrf2} 2^{-/-}\right)$ mice. Formalin-fixed lung tissue sections were processed and stained with $\mathrm{H} \& \mathrm{E}$ at $1 \mathrm{~d}$ post-intranasal (IN) instillation (A) and Masson's trichrome (B) at $5 \mathrm{~d}$ post-IN instillation of vehicle or RSV in mice neonatally exposed to $\mathrm{O}_{2}$ or room air. $\mathrm{BR}=$ bronchi or bronchiole; $\mathrm{AV}=$ alveoli; $\mathrm{BV}=\mathrm{blood}$ vessel. Arrows = injured regions (inflammation, alveolar thickening and vacuolization, bronchial epithelium/smooth muscle thickening). Blue in trichrome staining = collagen accumulation in fibrogenic regions (higher magnifications in insets). Bars $=100 \mu \mathrm{m}$.

\subsubsection{NRF2-Dependent Potentiation of Lung Viral Replication}

Compared to air/RSV-Nrf2 ${ }^{+/+}$mice, RSV N and G gene expressions were significantly higher in air/RSV-Nrf2 $2^{-1-}$ mice at $1 \mathrm{~d}$ (G gene) and $5 \mathrm{~d}$ (N and $\mathrm{G}$ genes) (Figure 3A). Neonatal $\mathrm{O}_{2}$ exposure significantly potentiated RSV gene replication in $\mathrm{Nrf2} 2^{+/+}(1 \mathrm{~d}$ and $5 \mathrm{~d}$ ) and $\mathrm{Nrf2^{-/- }}(5 \mathrm{~d})$ mice (Figure $\left.3 \mathrm{~A}\right) . \mathrm{O}_{2}$-augmented RSV gene replication was higher, but not statistically significant, in $\mathrm{Nrf2}^{-/-}$mice compared to $\mathrm{Nrf2}^{+/+}$mice (Figure 3A).

\subsubsection{NRF2-Dependent Potentiation of Serum IgE Increase}

Serum IgE level detected as a marker for RSV-induced bronchial epithelial hyperplasia/smooth muscle thickening was significantly greater in $\mathrm{Nrf2}^{-/-}$mice exposed to neonatal air compared with neonatal air/vehicle-Nrf2 $2^{-/-}$mice at $1 \mathrm{~d}$ and $5 \mathrm{~d}$ post-RSV (Figure 3B). Neonatal $\mathrm{O}_{2}$ exposure further heightened circulating IgE level in $\mathrm{Nrf2}{ }^{-/}$mice at $1 \mathrm{~d}$ post-RSV, which was not evident in $\mathrm{Nrf2}^{+/+}$mice (Figure 3B).

\subsubsection{NRF2-Dependent Augmentation of Lung Oxidative Stress}

Oxidation levels of endogenous macromolecules, proteins, and lipids, were measured to estimate the lung oxidative stress at $5 \mathrm{~d}$ post-IN. RSV infection significantly increased BAL oxidized lipid contents (determined as MDA levels) only in neonatal $\mathrm{O}_{2}$-exposed groups, and it was significantly more increased in $\mathrm{O}_{2} / \mathrm{RSV}_{-} \mathrm{Nrf2^{- }} /{ }^{-}$mice than in $\mathrm{O}_{2} / \mathrm{RSV}$ $\mathrm{Nrf2}^{+/+}$mice (Figure $4 \mathrm{~A}$ ). The amount of oxidized protein carbonyl was significantly higher basally (air/vehicle) in Nrf2 $2^{-/-}$mice than in $\mathrm{Nrf2}^{+/+}$mice (Figure 4B). Relative to $\mathrm{O}_{2} /$ vehicle groups, oxidized protein level in $\mathrm{O}_{2} / \mathrm{RSV}$ groups was significantly greater 
in both $\mathrm{Nrf2} 2^{-/-}$and $\mathrm{Nrf2} 2^{+/+}$mice and it was significantly more potentiated in $\mathrm{O}_{2} / \mathrm{RSV}$ $\mathrm{Nrf2}^{-/-}$mice than in $\mathrm{O}_{2} / \mathrm{RSV}_{-\mathrm{Nrf2}}{ }^{+/+}$mice (Figure $4 \mathrm{~B}$ ).

A

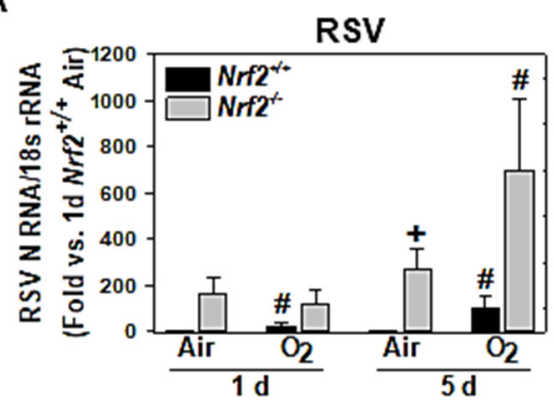

B

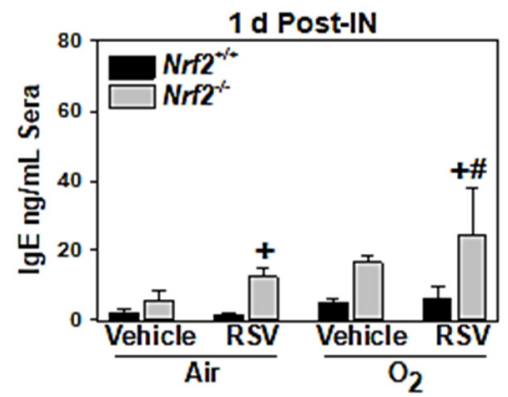

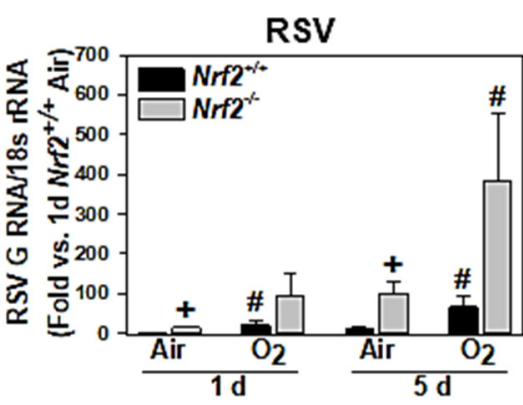

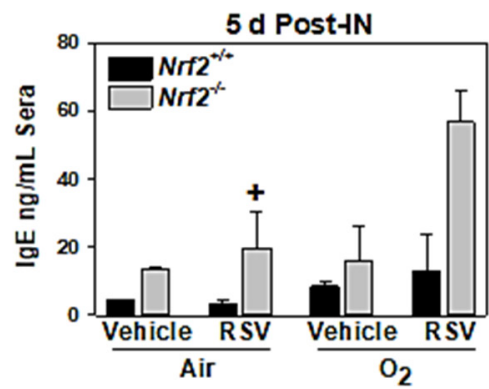

Figure 3. Differential lung respiratory syncytial virus (RSV) expression and serum IgE level in wild-type $\left(\mathrm{Nrf2}^{+/+}\right)$and Nrf2-deficient $\left(\mathrm{Nrf2}^{-/-}\right)$mice. (A) qRT-PCR determined relative pulmonary RSV N and G gene expressions compared to the level of air/RSV-Nrf2 $2^{+/+}$mice at $1 \mathrm{~d}$ post-intranasal (IN) instillation. (B) Serum IgE concentration was determined by mouse-specific ELISA. Mean \pm S.E.M. $\left(n=3\right.$ /group) presented. + , significantly different from exposure/treatment-matched $\mathrm{Nrf2} 2^{+/+}$ mice $(p<0.05)$. \#, significantly different from genotype-matched, air $/ \mathrm{RSV}(p<0.05) . \mathrm{O}_{2}=$ hyperoxia.

\subsubsection{Lung Nrf2 and ARE-Bearing Antioxidant Enzyme Expression}

Pulmonary Nrf2 mRNA abundance was significantly increased by RSV infection at $1 \mathrm{~d}$ and $5 \mathrm{~d}$ in air-exposed $\mathrm{Nrf2}^{+/+}$mice compared to time-matched air/vehicle- $\mathrm{Nrf2} 2^{+/+}$ mice (Figure 4C). Neonatal exposure to $\mathrm{O}_{2}$ also significantly upregulated the lung $N r f 2$ mRNA expression compared to air/vehicle at both time points (Figure 4C). Compared to air/RSV-Nrf2 $2^{+/+}$mice, Nrf2 message was significantly heightened in $\mathrm{O}_{2} / \mathrm{RSV}_{-} \mathrm{Nrf2} \mathrm{2}^{+/+}$mice (Figure 4C). RSV infection significantly induced pulmonary Gstp1 expression at $1 \mathrm{~d}$ (in air group) and $5 \mathrm{~d}$ (in $\mathrm{O}_{2}$ group) in $\mathrm{Nrf2}^{+/+}$mice (Figure 4D). Gstp1 and Gclc mRNA levels were significantly enhanced in $\mathrm{O}_{2} / \mathrm{RSV}-\mathrm{Nrf2} 2^{+/+}$mice than in air/RSV-Nrf2 ${ }^{+/+}$mice at $5 \mathrm{~d}$ (Figure $4 \mathrm{D}$ ). Abundance of these antioxidant enzyme genes was relatively or significantly lower in most experimental groups of $\mathrm{Nrf2}^{-/-}$mice compared to time- and exposurematched $\mathrm{Nrf2}^{+/+}$mice (Figure 4D).

\subsection{Effect of Prenatal SFN on Neonatal Hyperoxia-Induced Lung Injury}

\subsubsection{Decreased Lung Injury in Neonates Supplemented with Prenatal SFN}

Hyperoxia-induced lung injury determined by BAL neutrophil MPO concentration (a marker of neutrophilia), epithelial cell injury (a marker of epithelial sloughing), LDH level (a marker of lung damage and cytotoxicity), and total protein (a marker of edema and hyperpermeability) were relatively mild in $\mathrm{Nrf2^{+/+ }}$ neonates compared to $\mathrm{Nrf2} 2^{-/-}$ neonates (Figure 5A). Significantly reduced epithelial cell number and LDH were found in hyperoxia-exposed $\mathrm{Nrf2}^{+/+}$neonates from gestational SFN supplemented dams (Figure 5A). In Nrf2 $2^{-/-}$pups, prenatal SFN significantly reduced hyperoxia-increased MPO and LDH levels (Figure 5A). There was no significant effect of prenatal SFN on hyperoxia-induced lung edema in either genotype while it was significantly severe in $\mathrm{O}_{2} / \mathrm{PBS}-\mathrm{Nrf2} 2^{-/-}$pups compared to $\mathrm{O}_{2} / \mathrm{PBS}-\mathrm{Nrf2^{+/+ }}$ pups (Figure 5A). In Nrf2 ${ }^{+/+}$lungs, neonatal hyperoxia- 
caused alveolar hypotrophy accompanying focal cellular proliferation was lessened in the SFN-treated group relative to the PBS-treated group (Figure 5B). Decreased BAL cells lysis and infiltrated leukocytes were found in $\mathrm{SFN} / \mathrm{O}_{2}-\mathrm{Nrf2} 2^{+/+}$than in $\mathrm{PBS} / \mathrm{O}_{2}-\mathrm{Nrf2} 2^{+/+}$as shown by Giemsa staining (Figure 5B). In PBS-treated Nrf2 $2^{-/}$neonates, hyperoxia caused severe protein exudates and alveolar thickening indicating arrested saccular-to-alveolar transition (Figure 5B) as we reported previously [19]. Prenatal SFN markedly lessened these histopathologic phenotypes in Nrf2 $2^{-/-}$neonates (Figure 5B). We also found mitigation of inflammatory cell and congestion (filling of the alveoli with blood) in SFN/ $\mathrm{O}_{2}-\mathrm{Nrf2} 2^{-/-}$ neonates than in $\mathrm{PBS} / \mathrm{O}_{2}-\mathrm{Nrf2} 2^{-/-}$neonates (BAL cell cytospins, Figure 5B).

A

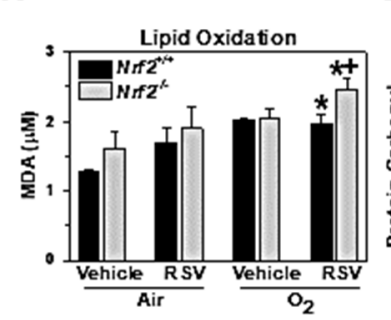

D

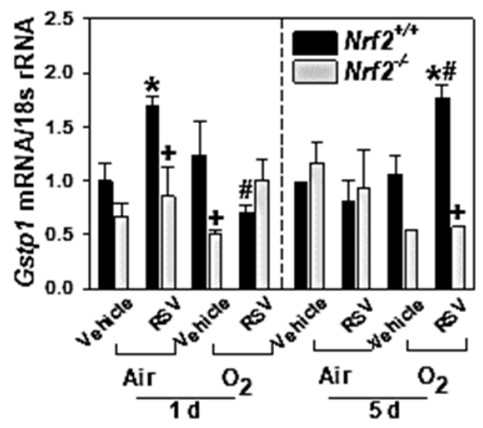

B

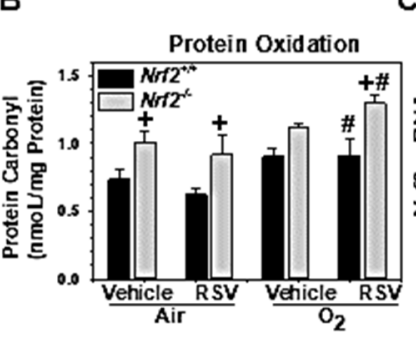

C

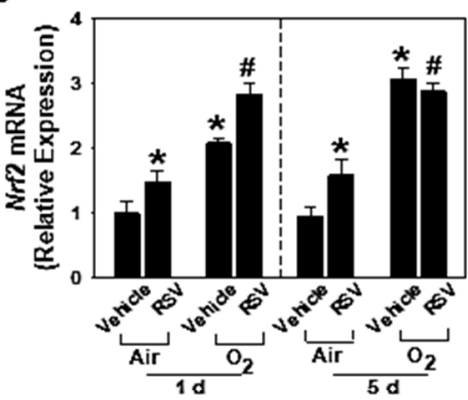

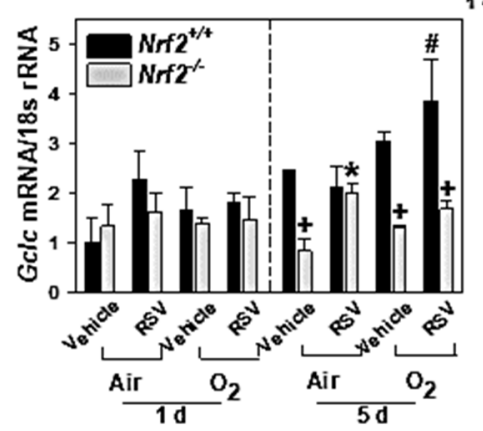

Figure 4. Differential oxidative damage markers and antioxidant expression in wild-type (Nrf2 $\left.{ }^{+/+}\right)$ and Nrf2-deficient (Nrf2 ${ }^{-/}$) mice. (A) Lung lipid oxidation determined by malondialdehyde (MDA) level in $50 \mu \mathrm{L}$ aliquots of bronchoalveolar lavage (BAL) fluids from each mouse ( $n=3-4$ /group). (B) Oxidized protein level in the lung determined by protein carbonyl amount in $1 \mu \mathrm{g}$ of total protein ( $n=3$ /group). (C) Lung Nrf2 mRNA expression determined by semi-quantitative RT-PCR ( $n=3$ /group). (D) Lung expressions of NRF2-dependent antioxidant enzyme genes, glutathiones-transferase P1 (Gstp1) and glutamate-cysteine ligase catalytic subunit (Gclc), were determined by quantitative RT-PCR ( $n=3$ /group). Mean \pm S.E.M. presented. ${ }^{*}$, significantly different from genotype matched air/vehicle controls $(p<0.05) .+$, significantly different from similarly treated and -exposed $N r f 2^{+/+}$mice $(p<0.05)$. \#, significantly different from genotype-matched air/RSV mice $(p<0.05)$. $\mathrm{O}_{2}=$ Hyperoxia.

\subsubsection{Detection of Gestational SFN Metabolites in Urine and Milk Bands}

HPLC-mass spectrometry detected SFN supplemented during gestation and its conjugated metabolites in milk bands (SFN-NAC, SFN) and urine (SFN-Cys, SFN-NAC, SFN) $8 \mathrm{~d}$ (PND4) after the last oral administration to foster dams (i.e., E17.5). Primary metabolites were SFN-Cys and SFN-NAC in neonate and foster urine samples, and unconjugated SFN was minimally detected (Figure 6A). In neonate milk bands, only unconjugated SFN and SFN-NAC were detected at PND4 (Figure 6B). Specimens of neonates from dams or dams given prenatal PBS had no SFN or its conjugates (SFN-Cys, SFN-GSH, SFN-NAC) detected. Metabolite levels or composition was not affected by genotype or exposure. 
A
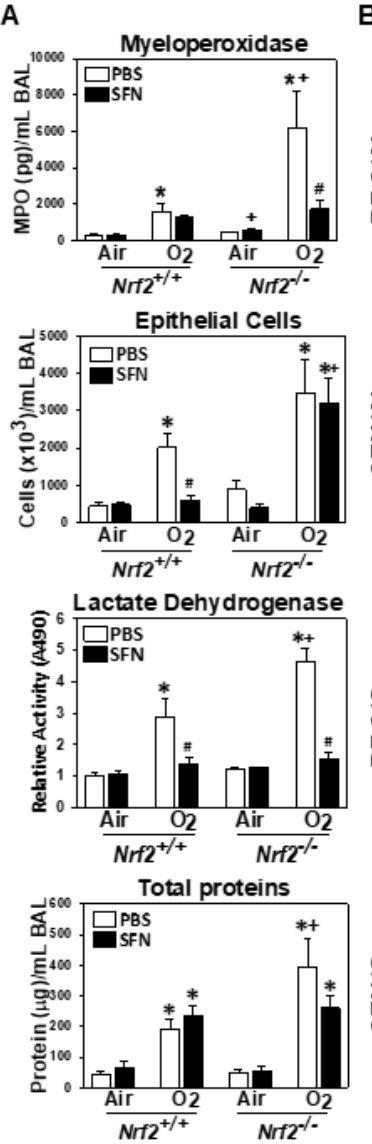
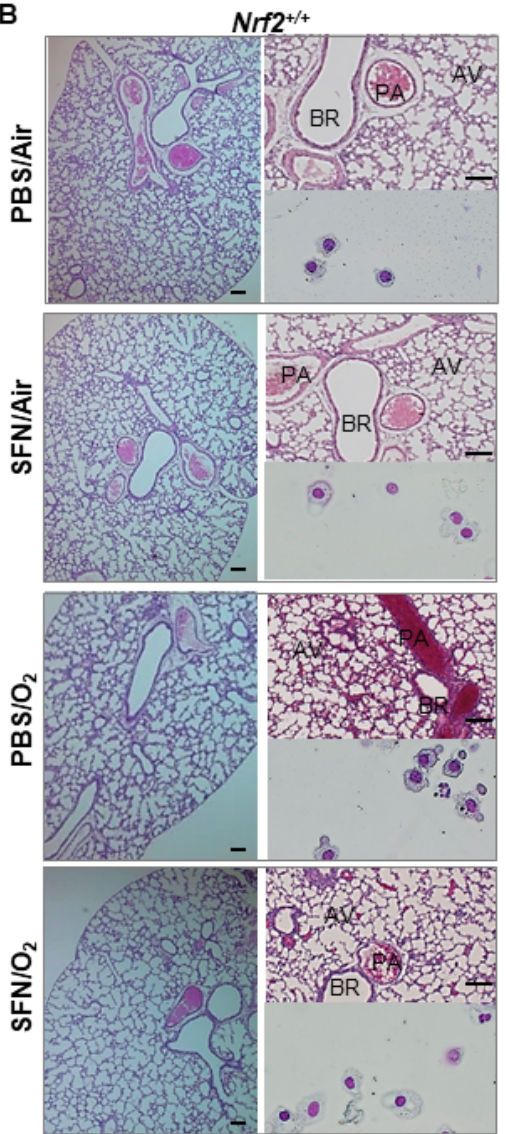
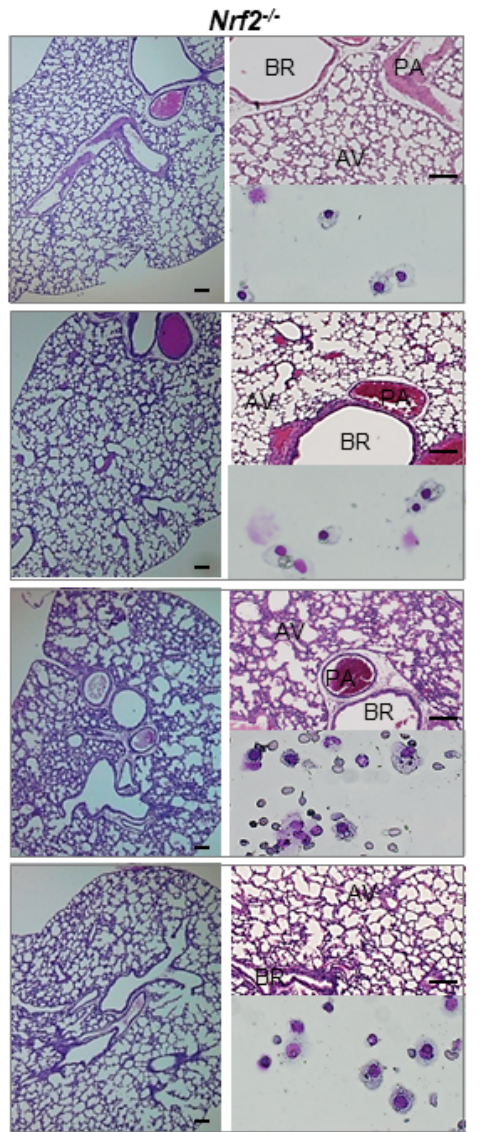

Figure 5. Effect of prenatal maternal sulforaphane on hyperoxia $\left(\mathrm{O}_{2}\right)$-induced lung injury in mouse neonates. (A) Lung injury was assessed by neutrophil myeloperoxidase (MPO) concentration, epithelial cell numbers, lactate dehydrogenase (LDH) level, and total protein concentration in bronchoalveolar lavage (BAL) fluids after 3-day exposure to $\mathrm{O}_{2}$ or room air exposure (PND1-PND4) to newborn mice given prenatal sulforaphane (SFN) or PBS. Group mean \pm S.E.M presented. ( $n=6-13$ /group). *, vs. genotype-matched PBS/air $(p<0.05)$. + , vs. prenatal treatment/exposure matched $\mathrm{Nrf2}^{+/+}(p<0.05)$. \#, vs. genotype matched $\mathrm{O}_{2} / \mathrm{PBS}(p<0.05)$. (B) H\&E-stained lung sections (lower and higher magnification light micrographs) and Giemsa-stained cytocentrifuged BAL cells (bottom right) depicted gestational SFN effects on neonatal lung injury by hyperoxia. $\mathrm{BR}=$ bronchi or bronchiole. $\mathrm{AV}=$ alveoli. $\mathrm{PA}=$ pulmonary artery. Bars $=50 \mu \mathrm{m}$.

\subsubsection{Decreased Oxidative Stress and Antioxidant Expression in Neonates by Prenatal SFN}

HPLC-mass spectrometry $\mathrm{Nrf}^{2 /+}$ neonates had lower magnitude of neonatal hyperoxiaincreased protein and lipid oxidation than $\mathrm{Nrf2}^{-/-}$neonates, and prenatal SFN treatment significantly suppressed the enhanced protein oxidation (Figure 7A). Gestational SFN significantly suppressed both lung protein and lipid oxidation in hyperoxiaexposed $\mathrm{Nrf2}^{-/-}$neonates (Figure 7A). However, the SFN-reduced protein and lipid oxidation levels in hyperoxia-exposed $\mathrm{Nrf2}^{-/-}$neonates were significantly higher than those in similarly exposed $\mathrm{Nrf2}^{+/+}$neonates (Figure 7A). Lung $\mathrm{Nrf2}$ mRNA expression was decreased in SFN $/ \mathrm{O}_{2}-\mathrm{Nrf2} 2^{+/+}$neonates than in $\mathrm{PBS} / \mathrm{O}_{2}-\mathrm{Nrf2} 2^{+/+}$neonates (Figure 7B). As we reported previously [19], ARE-bearing antioxidants, Gpx2 and $\mathrm{Nqo1}$, were transcriptionally induced by neonatal hyperoxia only in $\mathrm{Nrf2} 2^{+/+}$neonates (Figure 7C). Prenatal SFN treatment lowered the hyperoxia-induced antioxidant expressions in $\mathrm{Nrf2}^{+/+}$neonates (Figure 7C), indicating lowered oxidative stress by SFN. This corresponded to the lowered Nrf2 mRNA expression in SFN $/ \mathrm{O}_{2}-\mathrm{Nrf2} 2^{+/+}$pups (Figure 7B) and was consistent with the results of SFN pretreatment in adult $\mathrm{Nrf2}^{+/+}$ 
mice [23,33]. Message levels of Sod2, a NRF2-independent antioxidant enzyme, increased by hyperoxia in both genotypes were also decreased by maternal SFN (Figure 7C), indicating the role of reactive oxygen species-quenching direct antioxidants including SOD2 in reduced oxidation and inflammation of SFN $/ \mathrm{O}_{2}-\mathrm{Nrf2} 2^{-/-}$lungs.
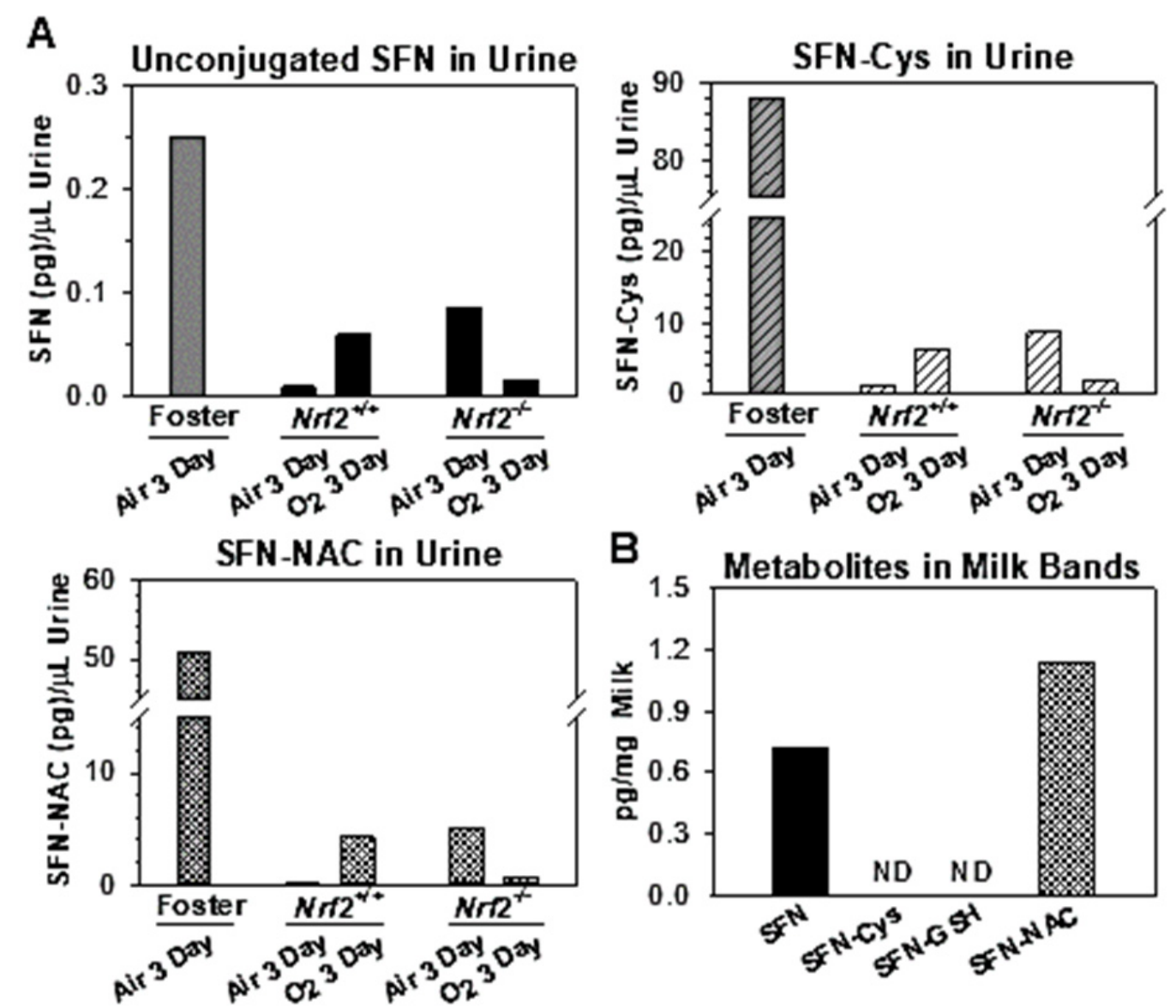

Figure 6. Sulforaphane (SFN) and metabolites detection. HPLC-mass spectrometry (ACE Excel 3 CN-ES $2.1 \times 100 \mathrm{~mm}$ ) determined SFN and its three major metabolites, SFN-N-acetyl cysteine (NAC), SFN-cysteine (Cys), and SFN-glutathione (GSH), in pooled neonate ( $n=8-13$ /group) and foster dam (Black Swiss; $n=2$ of SFN/Air) urine diluents or in deproteinated pooled milk band extracts $(n=2$ of SFN/air-Nrf2 $\left.2^{-/-}\right)$. Specimens were collected at PND4 after four oral doses of SFN $(9.4 \mu \mathrm{mol}$ at E11.5, 13.5, 15.5, 17.5) to foster dams. Samples were run three times and mean values are presented. $\mathrm{ND}=$ not detected. $\mathrm{O}_{2}=$ hyperoxia. Urine samples from gestational PBS treated foster dams and milk bands from their pups showed no metabolites detected.

\subsubsection{SFN Effects on Lung Transcriptomics}

Air-exposure. In air-exposed $N r f 2^{+/+}$neonates (PND4), SFN treatment significantly increased $(n=283)$ or decreased $(n=240)$ lung gene expressions relative to prenatal PBS (moderated $t$-test, $p<0.01$; Table 1 and Table S1). Prenatal SFN-altered $\mathrm{Nrf2}^{+/+}$ neonates genes included integrin binding sialoprotein (Ibsp), cathepsin K (Ctsk), AREresponsive antioxidants (e.g., Aldh3a1), Nrf2 heterodimerizing small Maf transcription factors (Maff, Mafg), and insulin-like growth factor binding protein 5 (Igfbp5) and they are proposed to be important in organ/cell development and growth (Figure 8A). In air-exposed $\mathrm{Nrf2}^{-/-}$neonates, prenatal SFN altered the expression of genes (moderated $t$-test, $p<0.01$; Table 1 and Table S2) including nuclear paraspeckle assembly transcript 1 (Neat1), olfactomedin 4 (Olfm4), NADPH oxidase 4 (Nox4), vascular endothelial growth factor A (Vegfa), Igfbp2, transformation related protein 53 (Trp53), and pathway analysis predicted their roles to favor cell morphogenesis and inhibit 
cell death and organismal injury/abnormality (Figure 8A). Venn diagram analysis indicated a significant dissociation of SFN-altered genes between air-exposed $\mathrm{Nrf2^{+/+ }}$ and $\mathrm{Nrf2} 2^{-/-}$neonates (Figure 8A) except 17 common genes such as transcription factors and developmental genes (e.g., Crygf, Zfp551, See Table 1). The baseline lung transcriptome changes by SFN were mostly less than twofold in both genotypes of mice (Table 1, Tables S1 and S2).

A
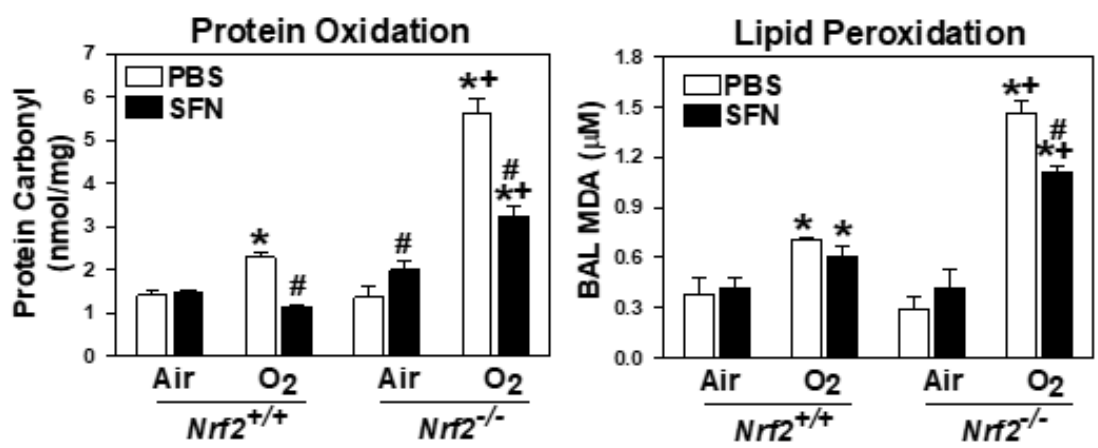

B
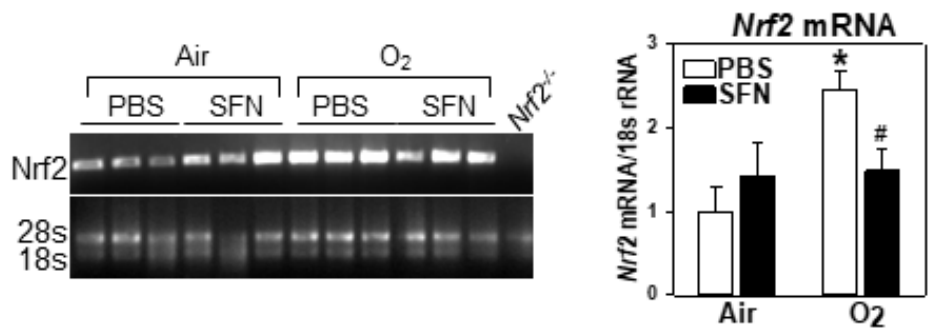

C
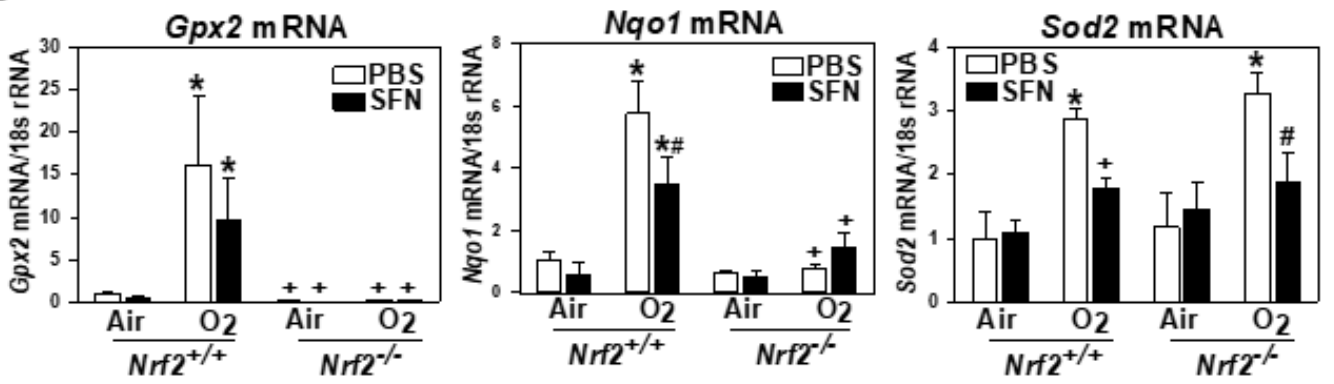

Figure 7. Oxidative damage markers and antioxidant expressions in wild-type $\left(\mathrm{Nrf2^{+/+ }}\right)$ and $\mathrm{Nrf2-}$ deficient $\left(\mathrm{Nrf2}^{-/}\right.$) mice. (A) Lung lipid oxidation determined by released malondialdehyde (MDA) level in $75 \mu \mathrm{L}$ aliquots of bronchoalveolar lavage (BAL) fluids from mouse ( $n=4$ /group). Oxidized protein level in the lung determined by protein carbonyl amount in $1 \mu \mathrm{g}$ of total protein ( $n=3$ /group). (B) Lung Nrf2 mRNA expression determined by semi-quantitative ( $1 \mathrm{~kb}$ amplicons) and quantitative RT-PCR ( $n=3$ /group). (C) Lung expressions of NRF2-dependent antioxidant enzyme genes, glutathione peroxidase 2 (Gpx2) and $\mathrm{NAD}(\mathrm{P}) \mathrm{H}$ dehydrogenase (quinone) 1 (Nqo1), and classical antioxidant superoxide dismutase 2 (Sod2) were determined by quantitative RT-PCR ( $n=3$ /group). Mean \pm S.E.M. presented. *, significantly different from genotype-matched PBS/Air controls $(p<0.05) .+$, significantly different from prenatal treatment/neonate exposure-matched $\mathrm{Nrf2} 2^{+/+}$mice $(p<0.05)$. \#, significantly different from genotype-matched PBS/hyperoxia $\left(\mathrm{O}_{2}\right)$ mice $(p<0.05)$. 
Table 1. Representative lung genes significantly changed by prenatal maternal sulforaphane (SFN) in air-exposed wild-type $\left(\mathrm{Nrf2} 2^{+/+}\right)$and Nrf2-deficient (Nrf2-/-) neonates at postnatal day (PND) 4.

\begin{tabular}{|c|c|c|c|c|}
\hline Genotype & ${ }^{+}$FC & Gene Symbol & Gene Title & Gene Ontology \\
\hline \multirow{18}{*}{ Nrf2+/+ } & 6.85 & $I b s p$ & integrin binding sialoprotein & cell adhesion \\
\hline & 5.31 & Ctsk & cathepsin K & proteolysis \\
\hline & 2.07 & Calcb & calcitonin-related polypeptide, beta & vasodilation \\
\hline & 2.05 & Lilrb4 & $\begin{array}{l}\text { leukocyte immunoglobulin-like } \\
\text { receptor, subfamily B, member } 4\end{array}$ & immune system process \\
\hline & 2.01 & Dnm3os & dynamin 3, opposite strand (Mir214) & \multirow{3}{*}{$\begin{array}{l}\text { skeletal system development } \\
\text { transcription } \\
\text { vascular endothelial growth factor } \\
\text { receptor signaling }\end{array}$} \\
\hline & 1.69 & Egr2 & early growth response 2 & \\
\hline & 1.69 & Myof & Myoferlin & \\
\hline & 1.53 & Aldh3a1 & $\begin{array}{l}\text { aldehyde dehydrogenase family } 3, \\
\text { subfamily A1 }\end{array}$ & response to hypoxia \\
\hline & 1.52 & Ereg & Epiregulin & angiogenesis \\
\hline & 1.49 & Igfbp5 & $\begin{array}{l}\text { insulin-like growth factor binding } \\
\text { protein } 5\end{array}$ & cell growth, glucose metabolism \\
\hline & 1.42 & Maff & $\begin{array}{l}\text { v-maf musculoaponeurotic } \\
\text { fibrosarcoma oncogene family, } \\
\text { protein F }\end{array}$ & $\begin{array}{l}\text { embryonic development, } \\
\text { transcription regulation }\end{array}$ \\
\hline & -1.64 & Gpr165 & G protein-coupled receptor 165 & signal transduction \\
\hline & -1.60 & Tspo2 & translocator protein 2 & transport \\
\hline & -1.56 & Bpgm & 2,3-bisphosphoglycerate mutase & glycolytic process \\
\hline & -1.52 & Lce1i & late cornified envelope 1I & epidermal development \\
\hline & -1.48 & Il20 & interleukin 20 & hemopoiesis \\
\hline & -1.42 & $N k x 2-9$ & NK2 homeobox 9 & respiratory tube development \\
\hline & 2.73 & Olfm4 & olfactomedin 4 & cell adhesion \\
\hline \multirow{15}{*}{$N r f 2^{-/-}$} & 2.66 & Neat1 & $\begin{array}{l}\text { nuclear paraspeckle assembly } \\
\text { transcript } 1\end{array}$ & cellular component maintenance \\
\hline & 2.46 & Meg3 & maternally expressed 3 & \multirow{3}{*}{$\begin{array}{l}\text { in utero embryonic development } \\
\text { negative regulation of peptidase } \\
\text { activity } \\
\text { carbohydrate metabolism }\end{array}$} \\
\hline & 2.33 & Stfa1 & stefin A1 & \\
\hline & 1.98 & Amy1 & amylase 1 , salivary & \\
\hline & 1.65 & Ptprc & $\begin{array}{l}\text { protein tyrosine phosphatase, } \\
\text { receptor type, C }\end{array}$ & MAPK activation \\
\hline & 1.55 & Cd14 & $\begin{array}{l}\text { CD14 antigen } \\
\text { sema domain, immunoglobulin }\end{array}$ & immune system process \\
\hline & 1.50 & Sema $4 a$ & $\begin{array}{l}\text { domain (Ig), transmembrane } \\
\text { domain (TM) and short cytoplasmic } \\
\text { domain, (semaphorin) } 4 \mathrm{~A}\end{array}$ & angiogenesis \\
\hline & 1.30 & $V e g f a$ & vascular endothelial growth factor A & angiogenesis \\
\hline & -2.48 & $C d a$ & cytidine deaminase & negative regulation of cell growth \\
\hline & -2.44 & St6gal2 & $\begin{array}{l}\text { beta galactoside alpha } 2,6 \\
\text { sialyltransferase } 2\end{array}$ & carbohydrate metabolism \\
\hline & -2.18 & Arsk & arylsulfatase $\mathrm{K}$ & metabolic process \\
\hline & -2.15 & $I g f b p 2$ & $\begin{array}{l}\text { insulin-like growth factor binding } \\
\text { protein } 2\end{array}$ & cell growth, response to stress \\
\hline & -1.67 & $C d c 25 c$ & cell division cycle $25 \mathrm{C}$ & \multirow{3}{*}{$\begin{array}{l}\text { mitotic cell cycle } \\
\text { cell activation, vessel remodeling } \\
\text { oxidation-reduction process } \\
\text { pppprocessremodeling }\end{array}$} \\
\hline & -1.61 & $\operatorname{Igf1}$ & insulin-like growth factor 1 & \\
\hline & -1.41 & Nox 4 & NADPH oxidase 4 & \\
\hline
\end{tabular}

SFN or PBS was orally administrated to foster dams on embryonic days 11.5, 13.5, 15.5, and 17.5. Microarray analysis was done with age PND4 tissues. ${ }^{\dagger}$ Fold change in SFN/air vs. PBS/air in each genotype. Full gene list in Supplementary Table S1 (prenatal SFN-altered 523 genes in $N r f 2^{+/+}$, moderated $t$-test with $p<0.01$ ) and Table S2 (prenatal SFN-altered 918 genes in $N r f 2^{-/-}$, moderated $t$-test with $p<0.01)$. Genes commonly altered by SFN in both genotypes includes Alport syndrome, mental retardation, midface hypoplasia and elliptocytosis chromosomal region gene 1 (Ammecr1), bromodomain containing 2 (Brd2), crystallin, gamma F (Crygf), cysteine rich tail 1 (Cysrt1), Dmx-like 2 (Dmxl2), E74-like factor 5 (Elf5), F-box and WD-40 domain protein 22 (Fbxw22), growth arrest-specific 2 like 3 (Gas2l3), leucine rich repeat containing 36 ( $\operatorname{rrc} 36)$, lymphocyte antigen 75 (Ly75), and zinc finger protein 551 (Zfp551). 
Hyperoxia-exposure. Similar to air controls, prenatal SFN-modulated lung genes in hyperoxia exposed neonates were also segregated between $\mathrm{Nrf2}^{+/+}$(2-Way ANOVA, $p$ $<0.01$ ) and $\mathrm{Nrf2}^{-/-}(2-$ Way ANOVA, $p<0.01)$ and only solute carrier family 25 (mitochondrial carrier, dicarboxylate transporter), member 10 (Slc25a10), MIF4G domain containing (Mif $4 g d$,), and centrosomal protein 128 (Cep128) were commonly changed by SFN in both strains (Figure 8B, Tables S3 and S4). In Nrf2 $2^{+/+}$neonates exposed to hyperoxia, transcriptome changes by prenatal SFN were favored to inhibit cell death and inflammation and activate cellular growth and development (Figure 8C). Increased organogenesis/development genes included protease, serine 35 (Prss35), Cep128 and decreased inflammatory genes included histocompatibility 2, D region locus 1 (H2-D1), CD40 antigen (Cd40), lipocalin 2 (Lcn2), and cadherin 22 (Cdh22) were evident in these mice treated with prenatal SFN (Table 2 and Table S3). In Nrf2 $2^{-1-}$ neonates exposed to hyperoxia, prenatal SFN decreased many hyperoxia-upregulated immune and inflammatory response genes as well as carcinogenesis-related genes including chemokine (C-C motif) ligand (Ccl9), B and T lymphocyte associated (Btla), and neutrophil cytosolic factors (e.g., Ncf4), lymphotoxin B (Ltb), selectin, platelet ligand (Selplg), C-type lectin domain family 7, member a (Clec7a), colony stimulating factor 2 receptor, beta, low-affinity (Csf2rb) (Figure 8D, Table 2 and Table S4). In addition, upregulation of many DNA repair/damage checkpoint genes such as tin interaction motif containing 1 (Uimc1), nei like 3 (Neil3), niblin ( $\mathrm{Nbn}$ ), and structural maintenance of chromosomes (Smc4, Smc6) compared to prenatal PBS treatment (Table 2 and Table S4). Insulin-induced gene 1 (INSIG1) and tumor necrosis factor ligand superfamily member 12 (TNFSF12) were among the potential upstream molecules affected by SFN in Nrf2 $2^{-/-}$transcriptome changes (Figure 8D). Although gestational SFN supplementation affected lung transcriptomics differentially in $\mathrm{Nrf2^{+/+ }}$ and $\mathrm{Nrf2^{-/- }}$ pups, pathway analysis indicated that NF- $\mathrm{KB}$ and MAPK/activator protein 1 (AP-1) may play key roles in the downstream molecular networks of lung genes changed by SFN in both strains (Figure 8C,D). Importantly, hyperoxia effects on up or down regulation pattern of gene expression in prenatal PBS-treated neonates were reversed by prenatal SFN (Table 2, Tables S3 and S4). That is, hyperoxia-suppressed genes (i.e., decreased in $\mathrm{PBS} / \mathrm{O}_{2}$ vs. PBS/Air) were mostly increased by prenatal SFN (i.e., higher in SFN $/ \mathrm{O}_{2}$ vs. PBS $/ \mathrm{O}_{2}$ ) and vice versa in both strains, indicating lowered hyperoxia-induced oxidative stress and inflammation in neonates given maternal SFN.

\subsubsection{SFN Effects on Placenta Transcriptomics}

At E18.5, SFN treatment significantly altered placenta transcriptomics compared to PBS treatment in both genotypes of mice ( $t$-test unpaired, $p<0.05)$. Transcriptome changes in $\mathrm{Nrf2}^{+/+}$placenta varied from those in $\mathrm{Nrf2} 2^{-/-}$placenta as illustrated in the heat map of hierarchical clustering analysis (Figure 9A). In $\mathrm{Nrf2}^{+/+}$placenta, genes involved in estrogen receptor signaling and reproductive system development such as Med subfamily, Igf1r, and nuclear receptor co-repressor 2 (Ncor2), vasculature and embryonic development including ADAM-like, decysin 1 (Adamdec1), platelet derived growth factor receptor, beta polypeptide (Pdgfrb), collagens including Colsa2, Sema3g, keratin 5 (Krt5), and late cornified envelope 1 subfamilies (e.g., Lce1a1), and prenatal death and cell morbidity-related genes (e.g., DNA methyltransferase 3A (Dnmt3a), Col4a2) were predicted to be inhibited by SFN (Figure 9B, Table 3 and Table S5). Multiple granzyme isozymes (Gzmd, Gzmg, Gzmf, Gzmc) and oxidoreduction genes including GST isozymes (e.g., Gstt1, Gstt2), peroxiredoxin 5 (Prdx5), hydroxyacid oxidase (glycolate oxidase) 3 (Hao3), hydroxysteroid (17-beta) dehydrogenase 10 (Hsd17b10), and peroxisomal trans-2-enoyl-CoA reductase (Pecr) were suppressed in $\mathrm{Nrf2} 2^{+/+}$placenta treated with SFN (Tables 3 and S5). Overall transcriptome changes indicated reduced cytotoxicity and activated feto-placenta barrier functions. Potential upstream molecules including prolactin (PRL, activated), immunoglobulins (inhibited), or various microRNAs such as miR-29b-3p (inhibited) were proposed to be affected by SFN 
in $\mathrm{Nrf2}^{+/+}$placenta transcriptome changes (Figure 9B). As seen in the postnatal lung transcriptomics, gestational SFN altered different placenta genes with similar cellular functions beneficial to host defense in $\mathrm{Nrf2}^{+/+}$and $\mathrm{Nrf2}^{-/-}$mice (Figure 9B,C). That is, SFN-altered transcriptome changes in $\mathrm{Nrf2}^{-/-}$placenta were predicted to inhibit prenatal death via regulation of genes including $I g f 2 r$, transforming growth factor, beta 2 (Tgfb2), AT rich interactive domain 5B (Arid5b), and IL-6 signal transducer (Il6st) and to activate angiogenesis and cell growth by alteration of genes such as tissue inhibitor of metalloproteinase 3 (Timp3), kinase insert domain protein receptor (Kdr), and Il6ra (Figure 9C, Tables 3 and S6). miR-21-5p was proposed to be one of the upstream regulators in SFN-altered $N r f 2^{-/-}$transcriptome changes for vascular development and prevention of cell death (Figure 9C). Pathway analysis revealed that MAPKs including ERK may be one of the key central players for crosstalk of SFN-altered genes in cellular organization and organ development processes in both genotypes (Figure 9B,C).

\subsubsection{Validation of Microarray and Pathway Analyses Results}

Neonate lung. NF-KB and MAPK/AP-1 have been determined to be potential central molecules in the networks of prenatal SFN-modulated genes in $\mathrm{Nrf2^{+/+ }}$ and $N r f 2^{-/-}$lungs exposed to hyperoxia (see Figure $8 \mathrm{C}, \mathrm{D}$ ). Hyperoxia-increased lung nuclear NF- $\mathrm{\kappa B}$ (p65)-DNA binding activity was significantly greater in $\mathrm{PBS} / \mathrm{O}_{2}-\mathrm{Nrf2} 2^{-/-}$ neonates than in PBS $/ \mathrm{O}_{2}-\mathrm{Nrf2} 2^{+/+}$neonates (Figure 10A). Activity was decreased in SFN-treated lungs of both strains but significant suppression of NF- $\mathrm{kB}$ activity was more evident in SFN $/ \mathrm{O}_{2}-\mathrm{Nrf2^{-/ }}$ neonates (Figure 10A). The magnitude of NF- $\mathrm{kB}$ activity in all experimental groups paralleled expression patterns of many immune and inflammatory response genes (see Table 2, Tables S3 and S4). Redox responsive c-Fos, an AP-1 transcription factor, was increased markedly after neonatal hyperoxia exposure in both strains (Figure 10B). Concurrent with the lung levels of SFN-reduced oxidative stress and direct antioxidant (Sod2) expression in hyperoxia-exposed $\mathrm{Nrf2}^{+/+}$ and $\mathrm{Nrf2}^{-/-}$lungs (see Figure 7A,C), the amount of c-Fos in both strains exposed to hyperoxia was lower in SFN-treated groups than in PBS-treated groups (Figure 10B). In addition, consistent with upregulation of multiple genes encoding DNA damage repair proteins in SFN $/ \mathrm{O}_{2}-\mathrm{Nrf2} 2^{-1-}$ mice than in $\mathrm{PBS} / \mathrm{O}_{2}-\mathrm{Nrf2} 2^{-/-}$mice, hyperoxiaenhanced nuclear DNA damage was significantly reduced in SFN $/ \mathrm{O}_{2}-\mathrm{Nrf2} 2^{-I-}$ lungs than in $\mathrm{PBS} / \mathrm{O}_{2}-\mathrm{Nrf2} 2^{-/-}$lungs. Significantly increased mitochondrial DNA damage was found only in PBS $/ \mathrm{O}_{2}-\mathrm{Nrf2} 2^{-/}$lungs, and prenatal SFN decreased mitochondrial DNA damage in Nrf2 $2^{-/-}$lungs (Figure 10C). Genomic and mitochondrial DNA damages were significantly less frequent in $\mathrm{Nrf2}^{+/+}$mice compared to $\mathrm{Nrf2} 2^{-/-}$mice, and they were not significantly altered by gestational SFN (Figure 10C).

Placenta. qRT-PCR confirmed significant induction of ubiquitin carboxy-terminal hydrolase L1 (Uchl1), one of the commonly altered placenta genes by SFN in both mice (Figure 10D). Prenatal SFN markedly reduced expression of Gstt1 and Adamdec1 expression in $N r f 2^{+/+}$placenta while they were barely expressed in PBS-treated $N r f 2^{-/-}$placenta (Figure 10D). Activated (phosphorylated) protein level of placenta $P$-ERK1/2, a molecule proposed to be important in the networks of SFN-altered placenta transcriptomics in both genotypes (see Figure $9 \mathrm{~B}, \mathrm{C}$ ) was heightened by SFN in both $\mathrm{Nrf2}^{+/+}$and $\mathrm{Nrf2}^{-/-}$placenta (Figure 10E). 
A
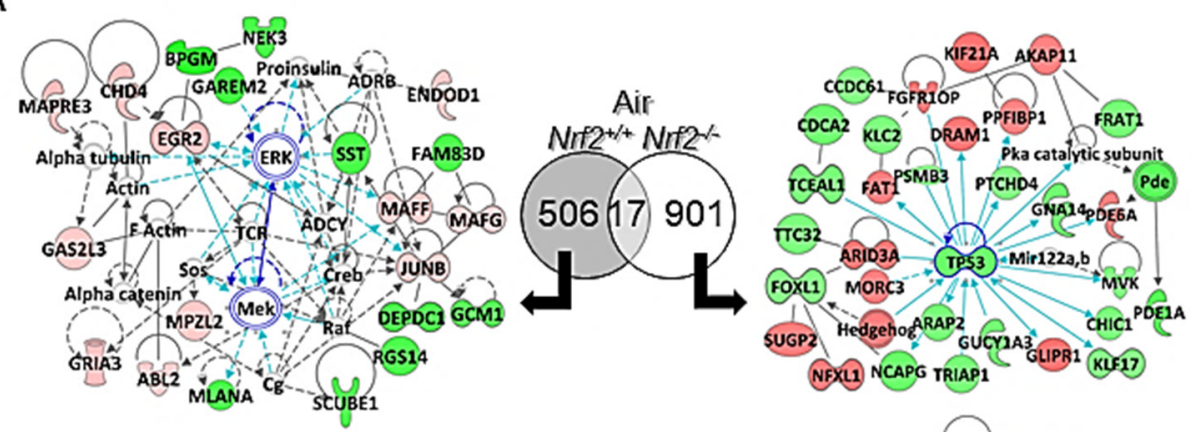

B
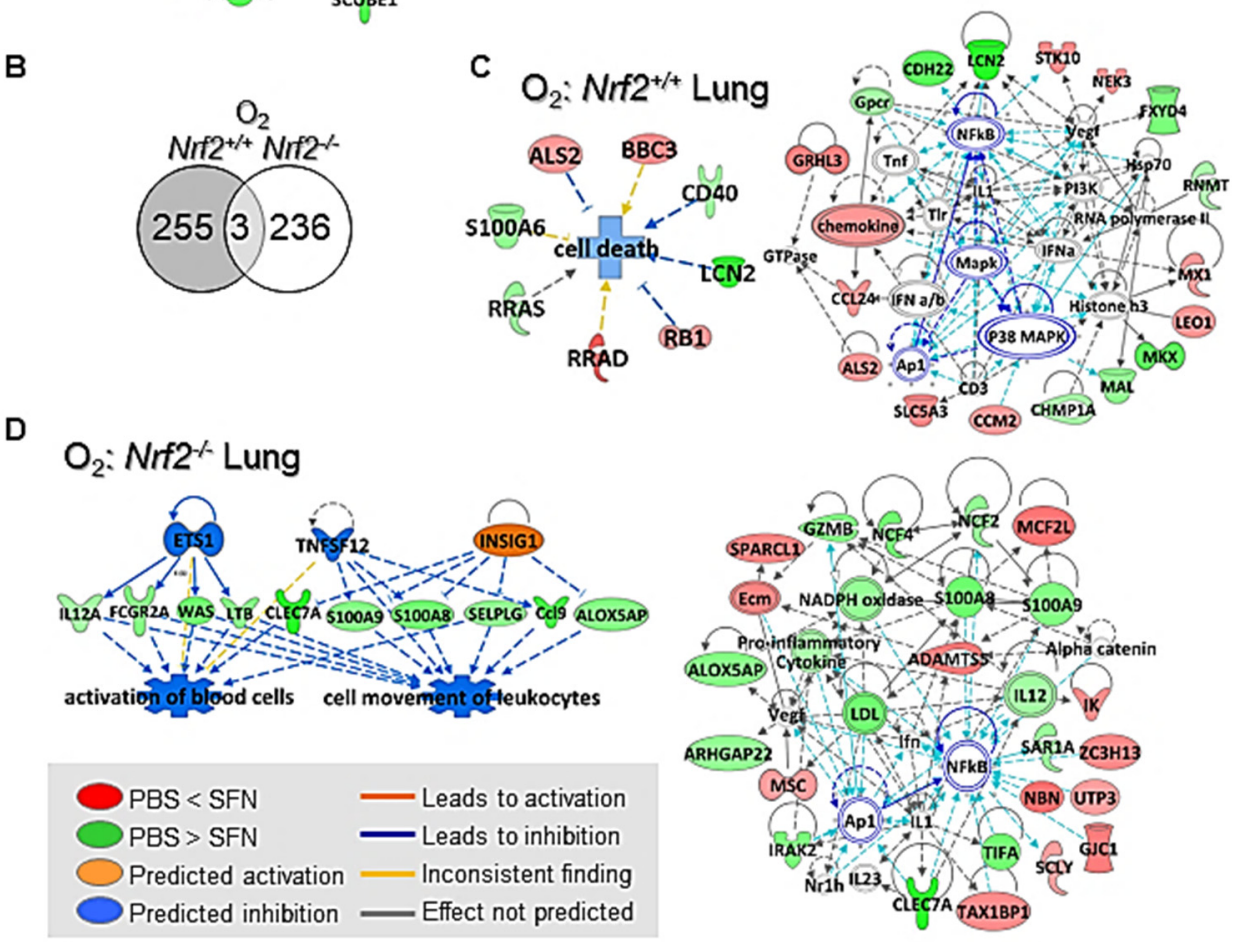

Figure 8. Lung transcriptome changes by prenatal sulforaphane (SFN) and affected biological functions and molecular networks predicted by pathway analyses in wild-type $\left(\mathrm{Nrf2}^{+/+}\right)$and $\mathrm{Nrf2-}$ deficient $\left(N r f 2^{-/-}\right)$neonates. (A) Prenatal SFN changed lung transcriptome differentially in airexposed $\mathrm{Nrf}^{+/+}(n=523)$ and in $N r f 2^{-/-}(n=918)$ neonates with 17 genes in common at postnatal day 4 (PND4). Pathway analysis demonstrated that mitogen-activated protein kinase (MAPK) cascade including extracellular-signal-regulated kinase (ERK) may play central roles in SFN-altered cell survival and organ growth and development transcriptome in $\mathrm{Nrf2} 2^{+/+}$lungs. In Nrf2-/- lungs, SFN mainly modulated genes facilitating cell morphology and cellular maintenance. (B) In neonate lungs exposed to hyperoxia $\left(\mathrm{O}_{2}\right)$, transcriptome changes by maternal SFN in Nrf2 $2^{++}(n=258)$ and $N r f 2^{-/-}(n=239)$ were different. Pathway analysis indicated that prenatal SFN effect in $\mathrm{O}_{2}$-exposed $\mathrm{Nrf2} 2^{+/+}$neonate lung favors to inhibit cell death and potentiate a network of tissue development (C), while SFN in $\mathrm{Nrf2} 2^{-/}$neonate lungs may inhibit upstream regulators such as tumor necrosis factor ligand (e.g., TNF12) to suppress inflammatory response genes and activate cell-to-cell signaling and cellular maintenance network genes (D). In both strains of neonates exposed hyperoxia, nuclear factor kappa-light-chain-enhancer of activated B cells (NF- $\mathrm{kB}$ ) and/or MAPK/AP-1 were predicted to play central roles in crosstalk of SFN-affected lung genes and their influence on cell/tissue functions. Molecular color and its intensity indicate up (red) or down (green) regulation degree of the genes by prenatal SFN compared to prenatal PBS after air or $\mathrm{O}_{2}$ exposure in each genotype. Ingenuity Pathway Analysis and GeneSpring software were used for data analyses. 
Table 2. Representative lung genes significantly changed by prenatal maternal sulforaphane (SFN) in hyperoxia-exposed wild-type $\left(\mathrm{Nrf2}{ }^{+/+}\right)$and $\mathrm{Nrf2}$-deficient $\left(\mathrm{Nrf2} 2^{-/-}\right)$neonates.

\begin{tabular}{|c|c|c|c|c|c|}
\hline Genotype & ${ }^{*} \mathrm{FC}$ by $\mathrm{O}_{2}$ & ${ }^{\dagger}$ FD PBS:SFN & Gene Symbol & Gene Title & Gene Ontology \\
\hline \multirow{17}{*}{ Nrf2+/+ } & -2.22 & 2.32 & $D k k 2$ & dickkopf homolog 2 & transcriptional regulation \\
\hline & -4.35 & 1.89 & Prss35 & protease, serine 35 & proteolysis, metabolism \\
\hline & -1.70 & 1.89 & Frem1 & $\begin{array}{l}\text { Fras1 related extracellular matrix } \\
\text { protein } 1\end{array}$ & cell communication \\
\hline & -2.33 & 1.86 & Rrad & Ras-related associated with diabetes & $\begin{array}{l}\text { negative regulation of cell } \\
\text { growth }\end{array}$ \\
\hline & -1.04 & 1.78 & Klhdc7a & $\begin{array}{l}\text { kelch domain containing 7A } \\
\text { (microRNA 2139) }\end{array}$ & protein binding \\
\hline & -1.46 & 1.61 & Fam26e & $\begin{array}{l}\text { family with sequence similarity } 26 \text {, } \\
\text { member E }\end{array}$ & transport \\
\hline & -1.55 & 1.52 & Cep128 & centrosomal protein 128 & microtubule organization \\
\hline & -1.29 & 1.28 & Ggt7 & gamma-glutamyltransferase 7 & glutathione metabolism \\
\hline & 3.50 & 1.19 & Ephx1 & epoxide hydrolase 1 , microsomal & response to toxicant \\
\hline & 4.39 & -3.07 & $\operatorname{Lcn} 2$ & lipocalin 2 & immune system process \\
\hline & 1.10 & -2.33 & $H 2-D 1$ & $\begin{array}{l}\text { histocompatibility } 2 \text {, D region } \\
\text { locus } 1\end{array}$ & $\mathrm{~T}$ cell mediated cytotoxicity \\
\hline & 1.82 & -2.29 & Cdh22 & cadherin 22 & cell adhesion \\
\hline & 2.13 & -2.28 & $M k x$ & mohawk homeobox & $\begin{array}{l}\text { negative regulation of } \\
\text { transcription }\end{array}$ \\
\hline & 3.03 & -2.19 & Msln & mesothelin & cell adhesion \\
\hline & 1.88 & -1.75 & $\operatorname{Tg} m 1$ & transglutaminase $1, \mathrm{~K}$ polypeptide & organ morphogenesis \\
\hline & 2.75 & -1.31 & Liph & lipase, member $\mathrm{H}$ & lipid metabolism \\
\hline & 1.98 & -1.28 & Ctsh & cathepsin $\mathrm{H}$ & $\mathrm{T}$ cell mediated cytotoxicity \\
\hline \multirow{19}{*}{$\operatorname{Nrf2} 2^{-/-}$} & -1.69 & 3.10 & Amy1 & amylase 1 , salivary & carbohydrate metabolism \\
\hline & -2.03 & 2.24 & Scara5 & $\begin{array}{l}\text { scavenger receptor class } \mathrm{A} \text {, } \\
\text { member } 5\end{array}$ & transport \\
\hline & -1.80 & 1.79 & Fap & fibroblast activation protein & proteolysis \\
\hline & -1.73 & 1.73 & Cep128 & centrosomal protein 128 & microtubule organization \\
\hline & -1.98 & 1.65 & $C c 2 d 2 a$ & $\begin{array}{l}\text { coiled-coil and C2 domain } \\
\text { containing 2A }\end{array}$ & cilium assembly \\
\hline & -1.71 & 1.64 & Uimc1 & $\begin{array}{l}\text { ubiquitin interaction motif } \\
\text { containing } 1\end{array}$ & DNA repair \\
\hline & -1.37 & 1.57 & Cep83 & centrosomal protein 83 & cilium assembly \\
\hline & -1.37 & 1.56 & $\mathrm{Nbn}$ & nibrin & DNA damage checkpoint \\
\hline & -2.11 & 1.51 & Smc4 & $\begin{array}{l}\text { structural maintenance of } \\
\text { chromosomes } 4\end{array}$ & DNA repair \\
\hline & 4.51 & -2.77 & Clec7a & $\begin{array}{l}\text { C-type lectin domain family } 7 \text {, } \\
\text { member a }\end{array}$ & $\begin{array}{l}\text { pattern recognition receptor } \\
\text { signaling }\end{array}$ \\
\hline & 1.89 & -2.40 & Cd52 & CD52 antigen & immune response \\
\hline & 4.53 & -2.26 & Ccl9 & chemokine (C-C motif) ligand 9 & chemotaxis \\
\hline & 1.67 & -1.67 & Ncf4 & neutrophil cytosolic factor 4 & cell communication \\
\hline & 1.66 & -1.67 & Tifa & $\begin{array}{l}\text { TRAF-interacting protein with } \\
\text { forkhead-associated domain }\end{array}$ & NF-kappa B signaling \\
\hline & 1.74 & -1.52 & $G z m b$ & $\begin{array}{l}\text { granzyme B } \\
\text { colony stimulating factor } 2 \text { receptor, }\end{array}$ & $\mathrm{T}$ cell mediated cytotoxicity \\
\hline & 2.11 & -1.46 & Csf $2 r b$ & $\begin{array}{l}\text { beta, low-affinity } \\
\text { (granulocyte-macrophage) }\end{array}$ & cytokine signaling \\
\hline & 2.16 & -1.46 & Cyp3a13 & $\begin{array}{l}\text { cytochrome P450, family } 3 \text {, } \\
\text { subfamily a, polypeptide } 13\end{array}$ & oxidation-reduction process \\
\hline & 1.46 & -1.45 & $L t b$ & lymphotoxin B & immune response \\
\hline & 1.58 & -1.40 & Selplg & selectin, platelet (p-selectin) ligand & leukocyte adhesion \\
\hline
\end{tabular}

SFN or PBS was orally administration to foster dams on embryonic days 11.5, 13.5, 15.5, and 17.5 and newborn pups were exposed to air or hyperoxia $\left(\mathrm{O}_{2}\right)$ for 3 days during postnatal days (PND) 1-4. Microarray was done for the lungs harvested at the end of exposure (PND4). ${ }^{*}$ Fold change (FC) by hyperoxia (PBS/hyperoxia) vs. PBS/air in each genotype. ${ }^{\dagger}$ Fold difference (FD) in SFN $/ \mathrm{O}_{2}$ vs. PBS/O $\mathrm{O}_{2}$ of each genotype. Full gene list in Supplementary Table S3 (Prenatal SFN-altered genes in hyperoxia-exposed Nrf2 ${ }^{+/+}, 2$-Way ANOVA with $p<$ $0.01 n=258$ ) and Table S4 (Prenatal SFN altered genes in hyperoxia-exposed Nrf2- $2^{-}$, 2-way ANOVA with $p<0.01, n=239$ ). Commonly altered genes in both genotypes are solute carrier family 25 (mitochondrial carrier, dicarboxylate transporter), member 10 (Slc25a10), MIF4G domain containing (Mif4gd), and centrosomal protein 128 (Cep128). 
A

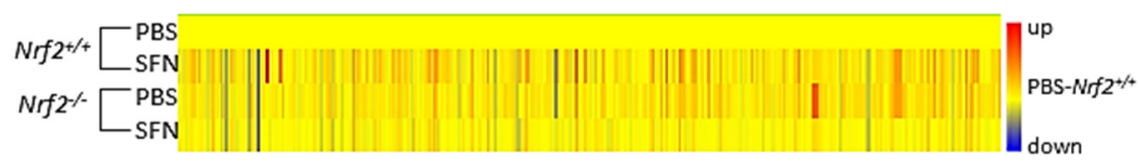

B

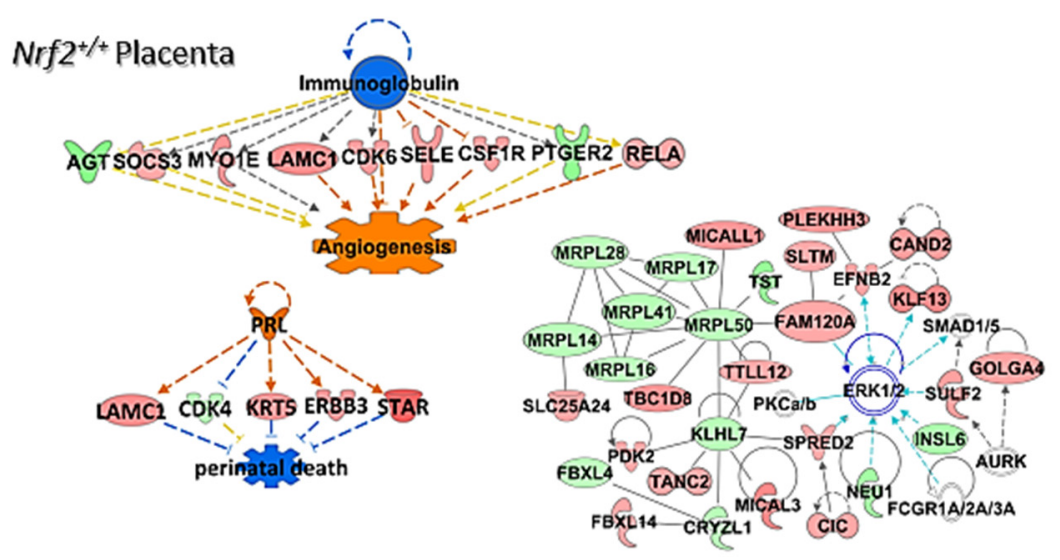

C

$\mathrm{Nrf2} \%$ Placenta
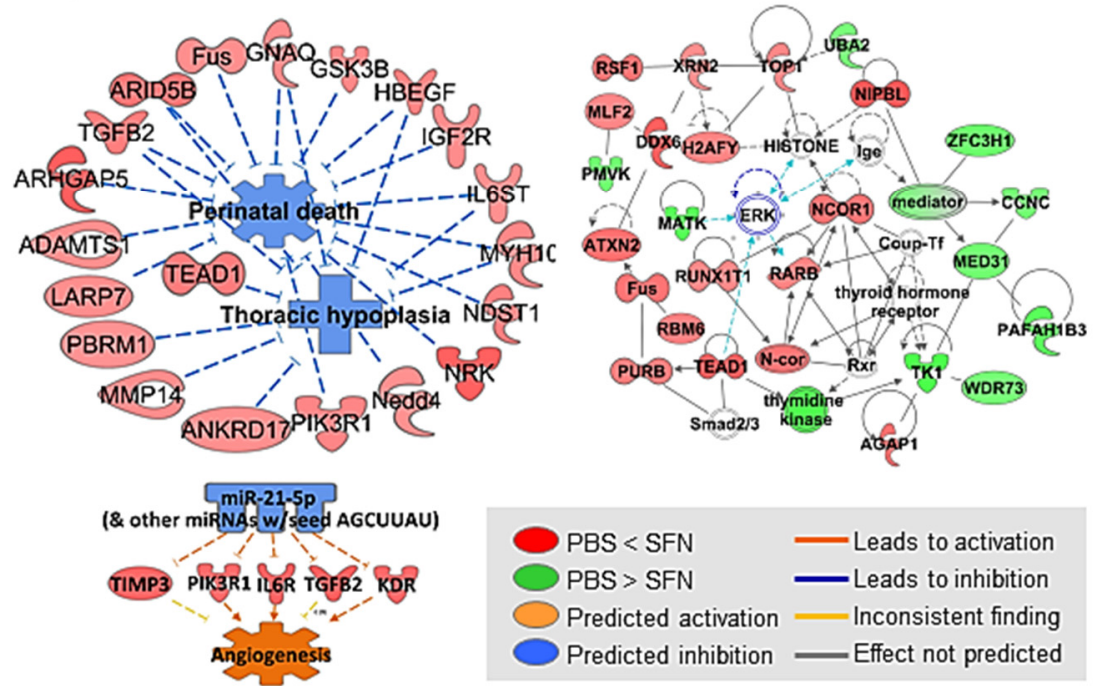

Figure 9. Placenta transcriptome changes by prenatal sulforaphane (SFN) and affected biological functions and molecular networks predicted by pathway analyses in wild-type $\left(\mathrm{Nrf2^{+/+ }}\right)$ and $\mathrm{Nrf2-deficient}\left(\mathrm{Nrf} 2^{-/^{-}}\right)$mice at embryonic day 18.5 . (A) Hierarchical clustering analysis generated a heap map depicting expression profiles of placenta genes altered by maternal SFN in $\mathrm{Nrf2}^{+/+}$mice and $\mathrm{Nrf2} 2^{-/-}$mice. Color bar indicates average expression intensity $(n=3 /$ group) normalized to PBS-Nrf2 $2^{+/+}$group. (B) Prenatal SFN modulated 814 placenta genes in $N r f 2^{+/+}$mice (1.5-fold changed 708 genes). Pathway analysis of SFN-altered transcriptome predicted inhibition of perinatal death and activation of vasculature development by upstream modulators prolactin (PRL) and immunoglobulin in $N r f 2^{+/+}$placenta. A key network of SFN-influenced $\mathrm{Nrf2}^{+/+}$placenta genes was connected with p42/p44 mitogen-activated protein kinase/extracellular-signal-regulated kinase (MAPK/ERK) and predicted to play roles in protein synthesis and cellular assembly and organization. (C) Prenatal SFN modulated 634 placenta genes in Nrf2 $2^{-/-}$mice (1.5-fold changed 367 genes). Pathway analysis of SFN-altered Nrf2 ${ }^{-/-}$ transcriptome also suggested potential inhibition of perinatal death and activation of vasculature development. MicroRNA miR-21-5p was suggested as one of the upstream modulators of $N r f 2^{-/-}$placenta transcriptome changes by maternal SFN. ERK was also predicted to play central roles in crosstalk of SFN-modulated $\mathrm{Nrf2} 2^{-/}$- placenta genes involved in cellular assembly and organization and organ development. Molecular color and its intensity indicate increased (red) or decreased (green) regulation degree of the genes by maternal SFN compared to maternal PBS in each genotype. Ingenuity Pathway Analysis and GeneSpring software were used for data analyses. 
Table 3. Representative genes significantly changed by prenatal maternal sulforaphane (SFN) in wild-type $\left(\mathrm{Nrf2^{+/+ }}\right)$ and Nrf2-deficient (Nrf2-/- $)$ placenta at embryonic day (E) 18.5.

\begin{tabular}{|c|c|c|c|c|}
\hline Genotype & ${ }^{\dagger}$ FC & Gene Symbol & Gene Title & Gene Ontology \\
\hline \multirow{24}{*}{$\mathrm{Nrf2+/+}$} & 7.33 & Stfa3 & stefin A3 & endopeptidase inhibitor \\
\hline & 4.33 & Tmem178 & transmembrane protein 178 & structural molecule activity \\
\hline & 3.69 & Uchl1 & ubiquitin carboxy-terminal hydrolase L1 & axonogenesis \\
\hline & 3.04 & Lce1d & late cornified envelope 1D & epidermal development \\
\hline & 2.92 & Colsa2 & collagen, type VIII, alpha 2 & morphogenesis \\
\hline & 2.88 & Slc6a2 & $\begin{array}{l}\text { solute carrier family } 6 \text { (neurotransmitter } \\
\text { transporter, noradrenalin), member } 2\end{array}$ & monoamine transport \\
\hline & 2.77 & Lor & loricrin & keratinocyte differentiation \\
\hline & 2.57 & Pdgfrb & $\begin{array}{l}\text { platelet derived growth factor receptor, } \\
\text { beta polypeptide }\end{array}$ & cell proliferation \\
\hline & 2.51 & Dnmt3a & $\begin{array}{l}\text { DNA methyltransferase } 3 \mathrm{~A} \\
\text { sema domain, immunoglobulin domain }\end{array}$ & DNA methylation \\
\hline & 2.19 & Sema3g & $\begin{array}{l}\text { (Ig), short basic domain, secreted, } \\
\text { (semaphorin) 3G }\end{array}$ & organ development \\
\hline & 1.97 & Pik3r1 & $\begin{array}{l}\text { phosphatidylinositol 3-kinase, regulatory } \\
\text { subunit, polypeptide } 1\end{array}$ & $\begin{array}{l}\text { insulin-like growth factor receptor } \\
\text { signaling pathway }\end{array}$ \\
\hline & 1.92 & Med13l & mediator complex subunit 13-like & transcription regulation \\
\hline & 1.55 & Aldh1l2 & $\begin{array}{l}\text { aldehyde dehydrogenase } 1 \text { family, member } \\
\text { L2 }\end{array}$ & oxidation reduction \\
\hline & -109.27 & Adamdec1 & ADAM-like, decysin 1 & proteolysis \\
\hline & -16.14 & $H 2-D 1$ & histocompatibility 2 , D region locus 1 & antigen processing and presentation \\
\hline & -7.84 & Lect1 & leukocyte cell derived chemotaxin 1 & organ development \\
\hline & -5.37 & Hao3 & hydroxyacid oxidase (glycolate oxidase) 3 & oxidation reduction \\
\hline & -4.43 & Gstt1/t2 & glutathione S-transferase, theta $1 / 2$ & glutathione metabolism \\
\hline & -4.11 & Gzmd & granzyme D & cytolysis \\
\hline & -3.86 & $I g f b p 1$ & insulin-like growth factor binding protein 1 & cell growth regulation \\
\hline & -1.80 & Conc & cyclin C & transcription regulation \\
\hline & -1.78 & Ndufaf1 & $\begin{array}{l}\text { NADH dehydrogenase (ubiquinone) } 1 \\
\text { alpha subcomplex, assembly factor } 1\end{array}$ & ubiquinone) activity \\
\hline & -1.69 & Irak1bp1 & $\begin{array}{l}\text { Interleukin- } 1 \text { receptor-associated kinase } 1 \\
\text { binding protein } 1\end{array}$ & NF-kappa B cascade \\
\hline & -1.68 & $\operatorname{Prdx} 5$ & peroxiredoxin 5 & oxidation reduction \\
\hline \multirow{16}{*}{$N r f 2^{-/-}$} & 4.71 & Lect1 & leukocyte cell derived chemotaxin 1 & organism development \\
\hline & 2.19 & Uchl1 & ubiquitin carboxy-terminal hydrolase L1 & response to ischemia \\
\hline & 2.16 & Ppargc1b & $\begin{array}{l}\text { peroxisome proliferative activated receptor, } \\
\text { gamma, coactivator } 1 \text { beta }\end{array}$ & transcription regulation \\
\hline & 1.95 & Arid5b & AT rich interactive domain $5 \mathrm{~B}$ & development \\
\hline & 1.74 & Hbegf & heparin-binding EGF-like growth factor & angiogenesis \\
\hline & 1.74 & Timp3 & tissue inhibitor of metalloproteinase 3 & neurotransmitter secretion \\
\hline & 1.72 & $K d r$ & kinase insert domain protein receptor & angiogenesis \\
\hline & 1.70 & Figf & c-fos induced growth factor & angiogenesis \\
\hline & 1.63 & $\operatorname{Ig} 2 r$ & insulin-like growth factor 2 receptor & post-embryonic development \\
\hline & -3.13 & Uty & $\begin{array}{l}\text { ubiquitously transcribed tetratricopeptide } \\
\text { repeat gene, Y chromosome }\end{array}$ & in utero embryonic development \\
\hline & -1.96 & Ccne2 & cyclin E2 & mitotic cell cycle \\
\hline & -1.73 & $T k 1$ & thymidine kinase 1 & DNA replication \\
\hline & -1.62 & Cox7a1 & cytochrome c oxidase subunit VIIa 1 & oxidation-reduction process \\
\hline & -1.59 & Cyp1a1 & $\begin{array}{l}\text { cytochrome } \mathrm{P} 450 \text {, family } 1 \text {, subfamily a, } \\
\text { polypeptide } 1\end{array}$ & response to hypoxia \\
\hline & -1.59 & Mir17hg & Mir17 host gene 1 & in utero embryonic development \\
\hline & -1.58 & Pafah1b3 & $\begin{array}{l}\text { platelet-activating factor acetylhydrolase, } \\
\text { isoform } 1 b \text {, subunit } 3\end{array}$ & lipid metabolic process \\
\hline
\end{tabular}

SFN or PBS was orally administration to foster dams on E11.5, E13.5, E15.5, and E17.5 and placenta were collected at E18.5. ${ }^{\dagger}$ Fold change (FC) by SFN vs. PBS in each genotype. Full gene list in Supplementary Table S5 (Prenatal SFN altered placenta genes in Nrf2 ${ }^{+/+}$, unpaired $t$-test with $p<0.05,1.5$-fold 708 genes out of 2427 genes) and Table S6 (Prenatal SFN altered placenta genes in Nrf2 $2^{-/-}$, unpaired $t$-test with $p<0.05 n=367$ out of 634 genes). Commonly altered genes in both genotypes including ubiquitin carboxy-terminal hydrolase L1 (Uchl1), Kruppel-like factors (Klf9, Klf7), and leukocyte cell derived chemotaxin 1 (Lect1) are marked in Table S6. 
A
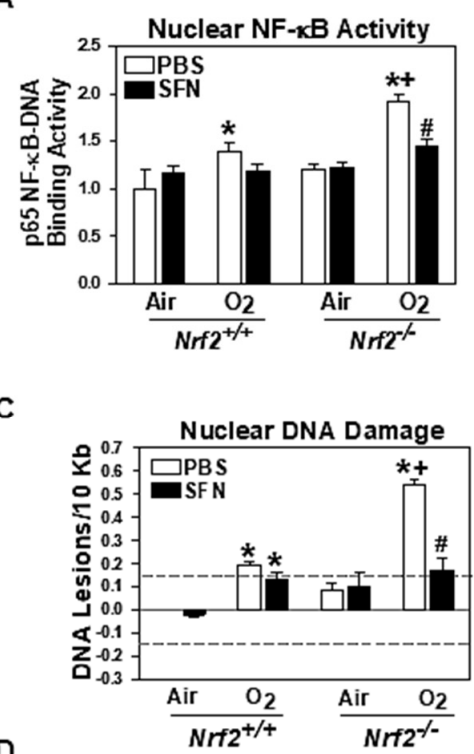

B

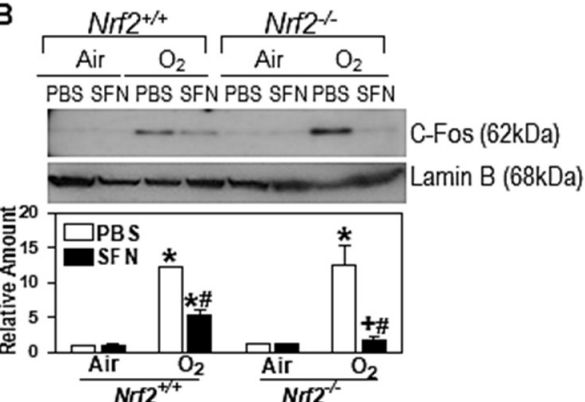

Mitochondrial DNA Damage

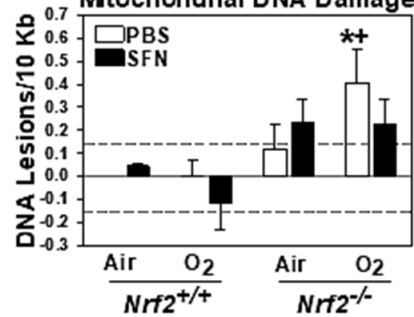

Uchl1 mRNA

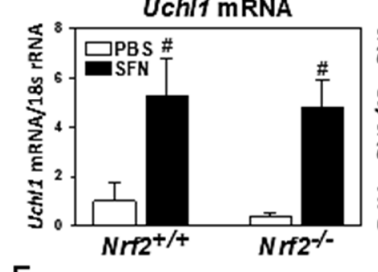

E

Gstt1 mRNA
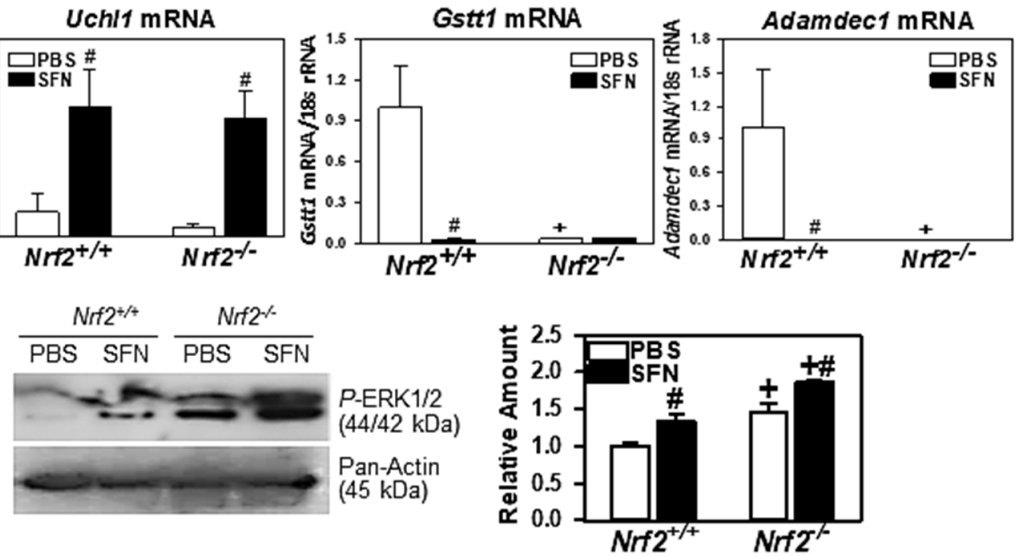

Figure 10. Validation of prenatal sulforaphane (SFN) effects on neonate lung and placenta transcriptome and signaling pathways. (A) Aliquots of nuclear proteins $(7 \mu \mathrm{g})$ were subjected to colorimetric DNA-binding activity assay for nuclear factor kappa-light-chainenhancer of activated B cells (NF-KB) p65 which was predicted to be involved in $\mathrm{Nrf}^{+/+}$and $\mathrm{Nrf}^{-/-}$neonate lung transcriptomics altered by maternal SFN after hyperoxia $\left(\mathrm{O}_{2}\right)$ exposure. Group mean \pm S.E.M presented ( $n=4$ /group). (B) Western blotting determined nuclear protein level of c-Fos transcription factor which was proposed to play roles in SFN-altered lung transcriptomics in $\mathrm{Nrf2}^{+/+}$and $\mathrm{Nrf}^{-/-}$neonates exposed to $\mathrm{O}_{2}$. Lamin B level was detected as a housekeeping control for nuclear proteins. Representative images from duplicate analyses presented. Scanned band images were quantitated by densitometry and relative protein band intensities normalize to PBS/air-Nrf2 ${ }^{+/+}$were depicted (mean \pm S.E.M.). $\mathrm{kDa}=$ kilodalton. (C) $\mathrm{qPCR}$ was performed to determine SFN-mediated changes in DNA base lesions caused by $\mathrm{O}_{2}$ in nuclear and mitochondrial genomes. Lesion frequencies in genomic (DNA polymerase $\beta$ gene) and mitochondrial DNA were compared in $N r f 2^{+/+}$and $N r f 2^{-/-}$neonate lungs after air or $\mathrm{O}_{2}$. All data were normalized to air-exposed $\mathrm{Nrf} 2^{+/+}$and group mean \pm S.E.M. presented ( $n=4$ /group). Background noise level (dashed lines) is set at \pm 0.15 . *, significantly different from genotype-matched PBS/Air controls $(p<0.05)$. + , significantly different from prenatal treatment/neonatal exposure matched $\mathrm{Nrf}^{+/+}$mice $(p<0.05)$. \#, significantly different from genotype-matched PBS/hyperoxia $\left(\mathrm{O}_{2}\right)$ mice $(p<0.05)$. (D) Placenta expressions of SFN-altered genes, ubiquitin carboxy-terminal hydrolase L1 (Uchl1), glutathione-s-transferase, theta 1 (Gstt1) and ADAM-like, decysin 1 (Adamdec1) were determined by qRT-PCR. Group mean \pm S.E.M. presented ( $n=3$ /group). (E) Western blotting determined placenta protein level of activated (phosphor) p42/p44 mitogen-activated protein kinase/extracellular signal-regulated kinase $(P$-ERK) which was proposed to play roles in SFN-altered placenta transcriptomics of $\mathrm{Nrf}^{+/+}$and $\mathrm{Nrf}^{-/-}$mice. Pan-actin level was determined as a housekeeping protein control for total proteins. Representative images from duplicate analyses presented. Scanned $P$-ERK band images were quantitated by densitometry and relative protein band intensities normalize to PBS- $N r f 2^{+/+}$were depicted (mean \pm S.E.M.). $\mathrm{kDa}=$ kilodalton. \#, significantly different from genotype-matched PBS controls $(p<0.05) .+$, significantly different from prenatal treatment matched $\mathrm{Nrf} 2^{+/+}$mice $(p<0.05)$. 


\section{Discussion}

The current study demonstrated that oxidative lung injury caused by hyperoxia during postnatal lung development increased pulmonary susceptibility to RSV-induced injury and inflammation in young adulthood, indicating long term respiratory consequences of BPD-like phenotypes. In addition, genetic deletion of murine Nrf2 further exacerbated RSV disease in later life. We also demonstrated that prenatal maternal administration of the phytochemical antioxidant SFN significantly reduced neonatal oxidative lung injury similar to BPD phenotypes in both $\mathrm{Nrf2}^{+/+}$and $\mathrm{Nrf2} 2^{-/-}$mice. The protective effects of gestational SFN were greater in hyperoxia-susceptible $N r f 2^{-/-}$pups than in hyperoxiaresistant $\mathrm{Nrf2}^{+/+}$pups, indicating NRF2-dependent and -independent mechanisms of SFN actions. Supporting this outcome, comparative transcriptome analysis in $\mathrm{Nrf2}^{+/+}$and $N r f 2^{-/-}$lungs determined that maternal SFN modulated different sets of genes involved in similar host defense pathways to facilitate lung cell survival and organ development and to suppress oxidative inflammation and DNA damage responses. Similarly, differential placenta transcriptome changes in $\mathrm{Nrf2}^{+/+}$and $\mathrm{Nrf2}^{-/-}$mice suggested a common beneficial role for prenatal SFN in utero signaling associated with inhibition of perinatal death and activation of angiogenesis.

Increasing evidence indicates that, compared to full-term infants, babies born prematurely are at significantly greater risk of adverse respiratory outcomes including BPD, respiratory failure, and infectious diseases [42-44]. Infants with BPD had increased risk of severe RSV disease relative to those without BPD [28,29]. Furthermore, low gestational age $(<32 \mathrm{wk})$ and low birth weight $(<1500 \mathrm{~g})$ are critical risk factors for infant RSV hospitalization [30,43-45]. Consistent with these clinical observations, we found that young adult mice that were exposed to hyperoxia at the saccular stage of neonatal lung development carried on persistent lung injury including impaired alveoli and focal fibrotic changes and predisposed to more severe RSV disease. In addition, these long-term outcomes and RSV susceptibility were NRF2-dependent as were the hyperoxia-caused BPD-like lung injury in neonate mice and RSV disease severity in adult mice [19,33]. McGrath-Morrow et al. [18] also demonstrated NRF2-dependent persistent BPD-like phenotypes, and neonatally hyperoxia-exposed juvenile $N r f 2^{-/-}$mice had greater delay in lung damage repair relative to similarly-exposed juvenile $\mathrm{Nrf2}^{+/+}$mice. Overall, our results indicate an essential role for NRF2-ARE-responsive defense and immune system in protection of prematurity with BPD against later life airway viral infection. Orally administered butylated hydroxyanisole, a NRF2 agonist, protected against RSV-induced lung oxidation, inflammation, viral replication, and airway hyperreactivity [34]. We also reported that RSV replication and lung neutrophilia was significantly decreased by SFN only in $\mathrm{Nrf2}^{+/+}$mice [33]. Moreover, SFN pretreatment significantly induced transcriptome of mitochondrial oxidative phosphorylation and energy metabolism and ameliorated hyperoxia-induced acute lung injury in adult mice [23]. The collective observations strongly suggest that therapeutic intervention of NRF2-ARE modulation may significantly impact RSV disease severity, post-BPD phenotypes, and perhaps other oxidative airway disorders in adulthood.

Recent research has highlighted the prenatal effects of functional foods or stimuli on postnatal offspring health to investigate the fetal determinants on human disorders. As we reported in the current study, beneficial effects of prenatal maternal SFN on fetal programming or postnatal health has been reported in model disorders. In spontaneously hypertensive stroke-prone rats, dietary supplementation of SFN precursor during pregnancy reduced oxidative stress and hypertension and offspring also had lower blood pressure and tissue inflammation tissue inflammation [46]. Prenatal SFN precursor diet also markedly decreased breast cancer growth in mice and the anti-carcinogenesis efficacy of prenatal diet regimen was greater than that of early postnatal or adulthood supplementation [47]. In mouse embryos, intraperitoneally given SFN significantly reduced maternal ethanol exposure-induced apoptosis [48]. In newborn mouse skin, maternal intraperitoneal SFN treatment prevented Krt14 mutation-related epidermis loses, and SFN was suggested to reprogram offspring keratin biosynthesis for skin integrity [35]. SFN nanoparticles in 
early chick culture alleviated heterocyclic aromatic amine compound-induced defects in central and peripheral nervous system and increased the embryo survival rate [49].

Unexpectedly, our results indicated that prenatal SFN-mediated postnatal protection against BPD-like phenotypes are not NRF2-dependent. Prenatal SFN markedly improved hyperoxia-caused severe BPD-like lung injury parameters in $N r f 2^{-/-}$pups while we observed relatively marginal protection by in utero SFN in hyperoxia-resistant $\mathrm{Nrf2^{+/+ }}$ pups. SFN is a strong NRF2 and ARE gene inducer for cytoprotection by NRF2 stabilization through inhibition of a cytoplasmic NRF2 inhibitor Kelch-like ECH-associated protein 1 (KEAP1) via its covalent binding to KEAP1 thiol groups [20,21]. However, SFN also acts through other mechanisms including NF- $\mathrm{kB}$ inhibition [50,51], MAPK activation [52,53], and histone deacetylase inhibition [54] for anti-inflammation, chemoprevention, apoptosis, and autophagy. From our microarray analyses, we found that gestational SFN supplementation affected different transcriptomes of postnatal lungs in Nrf2-sufficient and -deficient mice. However, pathway analyses indicated that similar biological functions were activated or inhibited by the SFN-altered genes in the two strains to prevent perinatal death and activate organogenesis. In addition, NF- $\mathrm{KB}, \mathrm{MAPK}$, and AP-1 were predicted to be common central components of crosstalk among the SFN-altered genes in both strains. These analyses indicated the role for these proteins in NRF2-independent protection by SFN. In support of these findings, we reported inhibition of hyperoxia-increased nuclear NF- $\mathrm{kB}$ activity and c-Fos level by SFN in postnatal lungs of two strains. SFN-induced decreased expressions of many NF- $\mathrm{KB}$ target inflammatory genes, particularly in $\mathrm{Nrf}^{-/-}$lungs (e.g., Ltb, S100a8, Il12a, Igll1, see Table 2 and Table S4), further supported SFN-mediated inhibition of NF- $\mathrm{kB}$ pathway in oxidative inflammation for neonate lung protection against hyperoxia. In addition to SFN, known NRF2 agonists include $N$-acetyl -L-cysteine, synthetic triterpenoids (e.g., CDDO-Im (1[2-Cyano-3,12-dioxooleana-1,9(11)-dien-28-oyl]imidazole), and resveratrol, curcumin, and oltipraz [22,55]. On the other hand, there are pipeline NRF2 antagonists (pharmacological inhibitors) as anti-cancer therapies because NRF2 provides growth advantage of tumor cells [56].

Studies have demonstrated that hyperoxia causes formation of DNA adducts such as 7,8-dihydro-8-oxo-guanine and DNA strand breakage in mouse lungs [57]. Relative to DNA adduct formation common in most lung cell types, phosphodiester backbone breakage is the most severe level of damage and was unique in type 2 cells, and it led to the cell death and lung injury [57]. Genetic loss of Nrf2 dysregulated redox homeostasis which promoted DNA lesions in neonatal lungs exposed to hyperoxia as seen previously [19]. Importantly, we determined in the present study that maternal SFN suppressed hyperoxia-induced nuclear and mitochondrial DNA damage in $\mathrm{Nrf2^{-/- }}$ neonate lungs, and it is postulated to be one of the NRF2-independent protective mechanisms of SFN. This was consistent with upregulation of multiple DNA repair/damage checkpoint genes (e.g., Uimc1, Nbn, Neil3, Smc4, Smc6, Tonsl, Wdr48, see Table S4) by SFN in hyperoxia-exposed Nrf2 ${ }^{-/}$lungs. Genes involved in microtubule assembly, chromatin modification, histone acetylation, and genetic imprinting in Nrf2 ${ }^{-/-}$lungs (e.g., Cep128, Clip1, Dek, Arid4b, Tdrd3, Ehmt1) as well as in $\mathrm{Nrf2}^{+/+}$lungs (e.g., Stk10, Cep128, Drosha, Phf20) were also increased by maternal SFN, indicating association of DNA methylation events (see Tables S3 and S4). Evidence indicated that hyperoxia causes increased DNA methylation (hypermethylation) in rat lung genes [58]. Lung epithelial cells also had hyperoxia-induced DNA damage which affected global DNA methylation status [59]. Studies with maternal SFN supplementation also suggested epigenetic alteration which was thought to underlie the positive effects of maternal SFN. In neural crest cells of mouse embryos, ethanol-induced reduction in histone acetylation at the $B c l 2$ promoter was reversed by SFN, and it may be involved in anti-apoptosis function of SFN [48]. In utero SFN also downregulated histone deacetylase 1 and increased histone acetylation in the mouse mammary tumors for reactivation of tumor suppressor genes (e.g., p16 and p53), and it may have governed the transcriptome changes affecting BRCA1 signaling pathway for anti-carcinogenesis [47]. Investigation 
of SFN-reprogramed epigenomes in embryonic and extra-embryonic tissues as well as postnatal lungs are further warranted.

A recent study found that NRF2 is critical in placenta integrity for fetal growth and reduced total and labyrinth volume of placenta in $N r f 2^{-/-}$mice at E18.5 was predicted to compromise and abolish the adaptational increase of nutrient transfer capacity to meet fetal growth demands [60]. Investigation of the NRF2 pathway detected significant compositional changes of amniotic fluids during late gestation and upregulated ARE-bearing epidermal differentiation complex genes, small proline-rich protein 2 (Sprr2d, Sprr2h), which reverted the defected epidermal barrier formation in loricrin (Lor)-deficient mouse embryos [61]. In the current study, we compared maternal SFN-induced placenta transcriptome changes between $\mathrm{Nrf2^{+/+ }}$ and $\mathrm{Nrf2^{-/- }}$ mice at E18.5. SFN significantly induced multiple epidermal differentiation complex genes (Lor and Lce1 subfamily genes) in $\mathrm{Nrf2^{+/+ }}$ placenta, but not in Nrf2 $2^{-/-}$placenta. However, the Nrf2 $2^{-/-}$placenta differentially responded to SFN and modulated compensatory epidermal/mesenchymal development (e.g., Lect1, Irs2, Arhgap5, Thoc2, Tead1) and angiogenesis (e.g., Hbegf, Kdr, Apold1) genes to reprogram the feto-placenta barrier function. Interestingly, we found that SFN-altered placenta genes such as Adamdec1, H2-D1, Gstt1, and Igfbp1 in Nrf2 ${ }^{+/+}$mice were also changed by maternal SFN in fetal lungs of the same gestation age. Pathway analyses also indicated similar functional networks (e.g., organ and system development, lipid metabolism, cell death and survival) affected by maternal SFN in placenta and fetal lungs.

In conclusion, we demonstrated that early-life oxidant-induced acute lung injury had significant consequences later in life on NRF2-dependent RSV susceptibility in mice. We also determined that increased antioxidant conditions in utero potentially contribute to a decreased risk of postnatal airway disease as we found that prenatal antioxidant SFN protected developing lungs from BPD-like oxidative pathogenesis in mice. Among the NRF2-independent protective mechanisms of SFN in Nrf2-/- lungs were upregulation of DNA damage repair molecules and NF- $\mathrm{kB}$ inhibition. Our study provided new insights into the infant oxidant lung injury severity influence on persistence of pulmonary morbidity and the therapeutic intervention for NRF2 agonists. Our results also provided justification for further studies on feto-placental barrier crossing of SFN metabolites and SFN-triggered molecular and epigenetic aspects of maternal cues for barrier and fetal lung signaling.

Supplementary Materials: The following are available online at https:/ / www.mdpi.com/article/10 .3390/antiox10121874/s1, Table S1: Prenatal sulforaphane-altered lung genes in postnatal air-exposed $N r f 2^{+/+}$mice $(n=523$, moderated $t$-test, $p \leq 0.01)$, Table S2: Prenatal sulforaphane-altered 918 lung genes in postnatal air-exposed $N r f 2^{-/-}$mice $(n=918$, moderated $t$-test, $p \leq 0.01)$, Table S3: Prenatal sulforaphane-neonatal hyperoxia interaction 258 genes in $\mathrm{Nrf2}^{+/+}$mice (2-Way ANOVA, $p \leq 0.01$ ), Table S4: Prenatal sulforaphane and neonatal hyperoxia interaction 239 genes in $\mathrm{Nrf}^{-/-}$mice (2-Way ANOVA, $p \leq 0.01)$, Table S5: Prenatal sulforaphane-modulated genes in Nrf2 $2^{+/+}$placenta $(t$-test unpaired, $p \leq 0.05$ ), Table S6: Prenatal sulforaphane-modulated genes in Nrf2 ${ }^{-/-}$placenta ( $t$-test unpaired, $p \leq 0.05$ ).

Author Contributions: Conceptualization, investigation, and resources, H.-Y.C. and S.R.K.; Methodology, H.-Y.C., L.M.-D., L.A.P., W.G., V.P. and F.B.L.; software and formal analysis, H.-Y.C., V.P. and F.B.L.; data curation and validation, H.-Y.C.; writing-original draft preparation, H.-Y.C.; writingreview and editing, H.-Y.C., L.M.-D., L.A.P., W.G., V.P., F.B.L. and S.R.K.; visualization, H.-Y.C.; supervision, project administration, and funding acquisition, S.R.K. All authors have read and agreed to the published version of the manuscript.

Funding: This research was supported by the Intramural Research Program of the NIEHS, National Institutes of Health, Department of Health and Human Services.

Institutional Review Board Statement: Animal use in the current study was approved by the Animal Care and Use Committee of NIEHS, NIH, U.S.A. (Animal Study Protocol 06-42 and 04-04 renewal approved on 13 February 2017).

Informed Consent Statement: Not applicable. 
Data Availability Statement: Microarray data are deposited in a public database repository (Gene Expression Omnibus accession numbers: GSE164699, GSE164700). Data is contained within the article or supplementary material.

Acknowledgments: Daniel Menendez and Xuting Wang in NIEHS provided excellent reviews of the manuscript.

Conflicts of Interest: The authors declare no conflict of interest.

\section{References}

1. Walsh, M.C.; Szefler, S.; Davis, J.; Allen, M.; Van Marter, L.; Abman, S.; Blackmon, L.; Jobe, A. Summary proceedings from the bronchopulmonary dysplasia group. Pediatrics 2006, 117, S52-S56. [CrossRef] [PubMed]

2. Ruaro, B.; Salton, F.; Braga, L.; Wade, B.; Confalonieri, P.; Volpe, M.C.; Baratella, E.; Maiocchi, S.; Confalonieri, M. The History and Mystery of Alveolar Epithelial Type II Cells: Focus on Their Physiologic and Pathologic Role in Lung. Int. J. Mol. Sci. 2021, 22, 2566. [CrossRef] [PubMed]

3. Aspal, M.; Zemans, R.L. Mechanisms of ATII-to-ATI Cell Differentiation during Lung Regeneration. Int. J. Mol. Sci. 2020, 21, 3188. [CrossRef]

4. Baraldi, E.; Filippone, M. Chronic lung disease after premature birth. N. Engl. J. Med. 2007, 357, 1946-1955. [CrossRef]

5. Jobe, A.H.; Bancalari, E. Bronchopulmonary dysplasia. Am. J. Respir. Crit. Care Med. 2001, 163, 1723-1729. [CrossRef] [PubMed]

6. Kalikkot Thekkeveedu, R.; Guaman, M.C.; Shivanna, B. Bronchopulmonary dysplasia: A review of pathogenesis and pathophysiology. Respir. Med. 2017, 132, 170-177. [CrossRef] [PubMed]

7. Skromme, K.; Vollsaeter, M.; Oymar, K.; Markestad, T.; Halvorsen, T. Respiratory morbidity through the first decade of life in a national cohort of children born extremely preterm. BMC Pediatr. 2018, 18, 102. [CrossRef]

8. Davidson, L.M.; Berkelhamer, S.K. Bronchopulmonary Dysplasia: Chronic Lung Disease of Infancy and Long-Term Pulmonary Outcomes. J. Clin. Med. 2017, 6, 4. [CrossRef]

9. Caskey, S.; Gough, A.; Rowan, S.; Gillespie, S.; Clarke, J.; Riley, M.; Megarry, J.; Nicholls, P.; Patterson, C.; Halliday, H.L.; et al. Structural and Functional Lung Impairment in Adult Survivors of Bronchopulmonary Dysplasia. Ann. Am. Thorac. Soc. 2016, 13, 1262-1270. [CrossRef]

10. Sillers, L.; Alexiou, S.; Jensen, E.A. Lifelong pulmonary sequelae of bronchopulmonary dysplasia. Curr. Opin. Pediatr. 2020, 32, 252-260. [CrossRef]

11. Warburton, D.; Gauldie, J.; Bellusci, S.; Shi, W. Lung development and susceptibility to chronic obstructive pulmonary disease. Proc. Am. Thorac. Soc. 2006, 3, 668-672. [CrossRef]

12. Warner, B.B.; Stuart, L.A.; Papes, R.A.; Wispe, J.R. Functional and pathological effects of prolonged hyperoxia in neonatal mice. Am. J. Physiol. 1998, 275, L110-L117. [CrossRef]

13. Yee, M.; White, R.J.; Awad, H.A.; Bates, W.A.; McGrath-Morrow, S.A.; O’Reilly, M.A. Neonatal hyperoxia causes pulmonary vascular disease and shortens life span in aging mice. Am. J. Pathol. 2011, 178, 2601-2610. [CrossRef] [PubMed]

14. McGrath-Morrow, S.A.; Lauer, T.; Collaco, J.M.; Yee, M.; O’Reilly, M.; Mitzner, W.; Neptune, E.; Wise, R.; Biswal, S. Neonatal hyperoxia contributes additively to cigarette smoke-induced chronic obstructive pulmonary disease changes in adult mice. Am. J. Respir. Cell Mol. Biol. 2011, 45, 610-616. [CrossRef]

15. O'Reilly, M.A.; Marr, S.H.; Yee, M.; McGrath-Morrow, S.A.; Lawrence, B.P. Neonatal hyperoxia enhances the inflammatory response in adult mice infected with influenza A virus. Am. J. Respir. Crit. Care Med. 2008, 177, 1103-1110. [CrossRef] [PubMed]

16. Cui, T.X.; Maheshwer, B.; Hong, J.Y.; Goldsmith, A.M.; Bentley, J.K.; Popova, A.P. Hyperoxic Exposure of Immature Mice Increases the Inflammatory Response to Subsequent Rhinovirus Infection: Association with Danger Signals. J. Immunol. 2016, 196, 4692-4705. [CrossRef] [PubMed]

17. Cho, H.Y.; Kleeberger, S.R. Association of Nrf2 with airway pathogenesis: Lessons learned from genetic mouse models. Arch. Toxicol. 2015, 89, 1931-1957. [CrossRef]

18. McGrath-Morrow, S.; Lauer, T.; Yee, M.; Neptune, E.; Podowski, M.; Thimmulappa, R.K.; O’Reilly, M.; Biswal, S. Nrf2 increases survival and attenuates alveolar growth inhibition in neonatal mice exposed to hyperoxia. Am. J. Physiol. Lung Cell. Mol. Physiol. 2009, 296, L565-L573. [CrossRef]

19. Cho, H.Y.; van Houten, B.; Wang, X.; Miller-Degraff, L.; Fostel, J.; Gladwell, W.; Perrow, L.; Panduri, V.; Kobzik, L.; Yamamoto, M.; et al. Targeted Deletion of Nrf2 Impairs Lung Development and Oxidant Injury in Neonatal Mice. Antioxid. Redox Signal. 2012, 17, 1066-1082. [CrossRef]

20. Kensler, T.W.; Egner, P.A.; Agyeman, A.S.; Visvanathan, K.; Groopman, J.D.; Chen, J.G.; Chen, T.Y.; Fahey, J.W.; Talalay, P. Keap1-nrf2 signaling: A target for cancer prevention by sulforaphane. Top. Curr. Chem. 2013, 329, 163-177. [CrossRef]

21. Dinkova-Kostova, A.T.; Holtzclaw, W.D.; Cole, R.N.; Itoh, K.; Wakabayashi, N.; Katoh, Y.; Yamamoto, M.; Talalay, P. Direct evidence that sulfhydryl groups of Keap1 are the sensors regulating induction of phase 2 enzymes that protect against carcinogens and oxidants. Proc. Natl. Acad. Sci. USA 2002, 99, 11908-11913. [CrossRef] 
22. Cho, H.Y.; Wang, X.; Li, J.; Bell, D.A.; Kleeberger, S.R. Potential therapeutic targets in Nrf2-dependent protection against neonatal respiratory distress disease predicted by cDNA microarray analysis and bioinformatics tools. Curr. Opin. Toxicol. 2016, 1, 125-133. [CrossRef] [PubMed]

23. Cho, H.Y.; Miller-DeGraff, L.; Blankenship-Paris, T.; Wang, X.; Bell, D.A.; Lih, F.; Deterding, L.; Panduri, V.; Morgan, D.L.; Yamamoto, M.; et al. Sulforaphane enriched transcriptome of lung mitochondrial energy metabolism and provided pulmonary injury protection via Nrf2 in mice. Toxicol. Appl. Pharmacol. 2019, 364, 29-44. [CrossRef]

24. Wise, R.A.; Holbrook, J.T.; Criner, G.; Sethi, S.; Rayapudi, S.; Sudini, K.R.; Sugar, E.A.; Burke, A.; Thimmulappa, R.; Singh, A.; et al. Lack of Effect of Oral Sulforaphane Administration on Nrf2 Expression in COPD: A Randomized, Double-Blind, Placebo Controlled Trial. PLoS ONE 2016, 11, e0163716. [CrossRef]

25. Egner, P.A.; Chen, J.G.; Zarth, A.T.; Ng, D.K.; Wang, J.B.; Kensler, K.H.; Jacobson, L.P.; Munoz, A.; Johnson, J.L.; Groopman, J.D.; et al. Rapid and sustainable detoxication of airborne pollutants by broccoli sprout beverage: Results of a randomized clinical trial in China. Cancer Prev. Res. 2014, 7, 813-823. [CrossRef] [PubMed]

26. Rudan, I.; O’Brien, K.L.; Nair, H.; Liu, L.; Theodoratou, E.; Qazi, S.; Luksic, I.; Fischer Walker, C.L.; Black, R.E.; Campbell, H.; et al. Epidemiology and etiology of childhood pneumonia in 2010: Estimates of incidence, severe morbidity, mortality, underlying risk factors and causative pathogens for 192 countries. J. Glob. Health 2013, 3, 010401. [CrossRef] [PubMed]

27. Scheltema, N.M.; Gentile, A.; Lucion, F.; Nokes, D.J.; Munywoki, P.K.; Madhi, S.A.; Groome, M.J.; Cohen, C.; Moyes, J.; Thorburn, K.; et al. Global respiratory syncytial virus-associated mortality in young children (RSV GOLD): A retrospective case series. Lancet Glob. Health 2017, 5, e984-e991. [CrossRef]

28. Paes, B.; Fauroux, B.; Figueras-Aloy, J.; Bont, L.; Checchia, P.A.; Simoes, E.A.; Manzoni, P.; Carbonell-Estrany, X. Defining the Risk and Associated Morbidity and Mortality of Severe Respiratory Syncytial Virus Infection Among Infants with Chronic Lung Disease. Infect. Dis. Ther. 2016, 5, 453-471. [CrossRef] [PubMed]

29. Chaw, P.S.; Hua, L.; Cunningham, S.; Campbell, H.; Mikolajczyk, R.; Nair, H.; Investigators, R. Respiratory Syncytial VirusAssociated Acute Lower Respiratory Infections in Children With Bronchopulmonary Dysplasia: Systematic Review and MetaAnalysis. J. Infect. Dis. 2019. [CrossRef]

30. Hall, C.B.; Weinberg, G.A.; Iwane, M.K.; Blumkin, A.K.; Edwards, K.M.; Staat, M.A.; Auinger, P.; Griffin, M.R.; Poehling, K.A.; Erdman, D.; et al. The burden of respiratory syncytial virus infection in young children. N. Engl. J. Med. 2009, 360, 588-598. [CrossRef]

31. American Academy of Pediatrics Committee on Infectious Diseases; American Academy of Pediatrics Bronchiolitis Guidelines Committee. Updated guidance for palivizumab prophylaxis among infants and young children at increased risk of hospitalization for respiratory syncytial virus infection. Pediatrics 2014, 134, 415-420. [CrossRef] [PubMed]

32. Acero-Bedoya, S.; Wozniak, P.S.; Sanchez, P.J.; Ramilo, O.; Mejias, A. Recent Trends in RSV Immunoprophylaxis: Clinical Implications for the Infant. Am. J. Perinatol. 2019, 36, S63-S67. [CrossRef] [PubMed]

33. Cho, H.Y.; Imani, F.; Miller-DeGraff, L.; Walters, D.; Melendi, G.A.; Yamamoto, M.; Polack, F.P.; Kleeberger, S.R. Antiviral activity of Nrf2 in a murine model of respiratory syncytial virus disease. Am. J. Respir. Crit. Care Med. 2009, 179, 138-150. [CrossRef]

34. Castro, S.M.; Guerrero-Plata, A.; Suarez-Real, G.; Adegboyega, P.A.; Colasurdo, G.N.; Khan, A.M.; Garofalo, R.P.; Casola, A. Antioxidant treatment ameliorates respiratory syncytial virus-induced disease and lung inflammation. Am. J. Respir. Crit. Care Med. 2006, 174, 1361-1369. [CrossRef] [PubMed]

35. Kerns, M.L.; DePianto, D.; Dinkova-Kostova, A.T.; Talalay, P.; Coulombe, P.A. Reprogramming of keratin biosynthesis by sulforaphane restores skin integrity in epidermolysis bullosa simplex. Proc. Natl. Acad. Sci. USA 2007, 104, 14460-14465. [CrossRef]

36. Ward, J.M.; Elmore, S.A.; Foley, J.F. Pathology methods for the evaluation of embryonic and perinatal developmental defects and lethality in genetically engineered mice. Vet. Pathol. 2012, 49, 71-84. [CrossRef]

37. Cho, H.Y.; Jedlicka, A.E.; Reddy, S.P.; Kensler, T.W.; Yamamoto, M.; Zhang, L.Y.; Kleeberger, S.R. Role of NRF2 in protection against hyperoxic lung injury in mice. Am. J. Respir. Cell Mol. Biol. 2002, 26, 175-182. [CrossRef]

38. Cho, H.Y.; Morgan, D.L.; Bauer, A.K.; Kleeberger, S.R. Signal transduction pathways of tumor necrosis factor-mediated lung injury induced by ozone in mice. Am. J. Respir. Crit. Care Med. 2007, 175, 829-839. [CrossRef]

39. Farraj, A.K.; Harkema, J.R.; Kaminski, N.E. Allergic rhinitis induced by intranasal sensitization and challenge with trimellitic anhydride but not with dinitrochlorobenzene or oxazolone in A/J mice. Toxicol. Sci. 2004, 79, 315-325. [CrossRef]

40. Santos, J.H.; Meyer, J.N.; Mandavilli, B.S.; Van Houten, B. Quantitative PCR-based measurement of nuclear and mitochondrial DNA damage and repair in mammalian cells. Meth. Mol. Biol. 2006, 314, 183-199.

41. Cho, H.Y.; Gladwell, W.; Yamamoto, M.; Kleeberger, S.R. Exacerbated airway toxicity of environmental oxidant ozone in mice deficient in Nrf2. Oxid. Med. Cell. Longev. 2013, 2013, 254069. [CrossRef] [PubMed]

42. Maitre, N.L.; Ballard, R.A.; Ellenberg, J.H.; Davis, S.D.; Greenberg, J.M.; Hamvas, A.; Pryhuber, G.S.; Prematurity and Respiratory Outcomes Program. Respiratory consequences of prematurity: Evolution of a diagnosis and development of a comprehensive approach. J. Perinatol. 2015, 35, 313-321. [CrossRef]

43. Doyle, L.W.; Ford, G.; Davis, N. Health and hospitalistions after discharge in extremely low birth weight infants. Semin. Neonatol. 2003, 8, 137-145. [CrossRef]

44. Bogdan, R.D.; Rusu, L.; Toma, A.I.; Nastase, L. Respiratory Outcome of the Former Premature Infants. J. Med. Life 2019, 12, 381-394. [CrossRef] 
45. Benitez-Guerra, D.; Pina-Flores, C.; Zamora-Lopez, M.; Escalante-Padron, F.; Lima-Rogel, V.; Gonzalez-Ortiz, A.M.; GuevaraTovar, M.; Bernal-Silva, S.; Benito-Cruz, B.; Castillo-Martinez, F.; et al. Respiratory syncytial virus acute respiratory infectionassociated hospitalizations in preterm Mexican infants: A cohort study. Influenza Other Respir. Viruses 2020, 14, 182-188. [CrossRef]

46. Noyan-Ashraf, M.H.; Wu, L.; Wang, R.; Juurlink, B.H. Dietary approaches to positively influence fetal determinants of adult health. FASEB J. 2006, 20, 371-373. [CrossRef]

47. Li, Y.; Buckhaults, P.; Li, S.; Tollefsbol, T. Temporal Efficacy of a Sulforaphane-Based Broccoli Sprout Diet in Prevention of Breast Cancer through Modulation of Epigenetic Mechanisms. Cancer Prev. Res. 2018, 11, 451-464. [CrossRef] [PubMed]

48. Yuan, F.; Chen, X.; Liu, J.; Feng, W.; Cai, L.; Wu, X.; Chen, S.Y. Sulforaphane restores acetyl-histone H3 binding to Bcl-2 promoter and prevents apoptosis in ethanol-exposed neural crest cells and mouse embryos. Exp. Neurol. 2018, 300, 60-66. [CrossRef]

49. Zhang, P.; Li, T.; Liu, C.; Sindi, M.; Cheng, X.; Qi, S.; Liu, X.; Yan, Y.; Bao, Y.; Brand-Saberi, B.; et al. Nano-sulforaphane attenuates PhIP-induced early abnormal embryonic neuro-development. Ann. Anat. 2021, 233, 151617. [CrossRef]

50. Heiss, E.; Herhaus, C.; Klimo, K.; Bartsch, H.; Gerhauser, C. Nuclear factor kappa B is a molecular target for sulforaphane-mediated anti-inflammatory mechanisms. J. Biol. Chem. 2001, 276, 32008-32015. [CrossRef]

51. Moon, D.O.; Kim, M.O.; Kang, S.H.; Choi, Y.H.; Kim, G.Y. Sulforaphane suppresses TNF-alpha-mediated activation of NF-kappaB and induces apoptosis through activation of reactive oxygen species-dependent caspase-3. Cancer Lett. 2009, 274, 132-142. [CrossRef]

52. Jo, C.; Kim, S.; Cho, S.J.; Choi, K.J.; Yun, S.M.; Koh, Y.H.; Johnson, G.V.; Park, S.I. Sulforaphane induces autophagy through ERK activation in neuronal cells. FEBS Lett. 2014, 588, 3081-3088. [CrossRef] [PubMed]

53. Keum, Y.S.; Yu, S.; Chang, P.P.; Yuan, X.; Kim, J.H.; Xu, C.; Han, J.; Agarwal, A.; Kong, A.N. Mechanism of action of sulforaphane: Inhibition of p38 mitogen-activated protein kinase isoforms contributing to the induction of antioxidant response elementmediated heme oxygenase-1 in human hepatoma HepG2 cells. Cancer Res. 2006, 66, 8804-8813. [CrossRef]

54. Ho, E.; Clarke, J.D.; Dashwood, R.H. Dietary sulforaphane, a histone deacetylase inhibitor for cancer prevention. J. Nutr. 2009, 139, 2393-2396. [CrossRef] [PubMed]

55. Cuadrado, A.; Manda, G.; Hassan, A.; Alcaraz, M.J.; Barbas, C.; Daiber, A.; Ghezzi, P.; Leon, R.; Lopez, M.G.; Oliva, B.; et al. Transcription Factor NRF2 as a Therapeutic Target for Chronic Diseases: A Systems Medicine Approach. Pharmacol. Rev. 2018, 70, 348-383. [CrossRef]

56. Robledinos-Anton, N.; Fernandez-Gines, R.; Manda, G.; Cuadrado, A. Activators and Inhibitors of NRF2: A Review of Their Potential for Clinical Development. Oxid. Med. Cell. Longev. 2019, 2019, 9372182. [CrossRef] [PubMed]

57. Barker, G.F.; Manzo, N.D.; Cotich, K.L.; Shone, R.K.; Waxman, A.B. DNA damage induced by hyperoxia: Quantitation and correlation with lung injury. Am. J. Respir. Cell Mol. Biol. 2006, 35, 277-288. [CrossRef]

58. Yue, X.; Fu, J.; Xue, X.; Gao, H.; Liu, D.; Zong, Z.; Wang, W.; Li, H.; Yuan, Z. Detection of p16 promoter methylation in premature rats with chronic lung disease induced by hyperoxia. Pediatr. Int. 2010, 52, 520-526. [CrossRef]

59. Panayiotidis, M.I.; Rancourt, R.C.; Pappa, A.; White, C.W. Effect of cell cycle growth arrest on global DNA methylation status in human lung epithelial-like (A549) cells. In Vivo 2006, 20, 861-865.

60. Kweider, N.; Huppertz, B.; Rath, W.; Lambertz, J.; Caspers, R.; ElMoursi, M.; Pecks, U.; Kadyrov, M.; Fragoulis, A.; Pufe, T.; et al. The effects of Nrf2 deletion on placental morphology and exchange capacity in the mouse. J. Matern. Fetal Neonatal. Med. 2017, 30, 2068-2073. [CrossRef]

61. Huebner, A.J.; Dai, D.; Morasso, M.; Schmidt, E.E.; Schafer, M.; Werner, S.; Roop, D.R. Amniotic fluid activates the nrf2/keap1 pathway to repair an epidermal barrier defect in utero. Dev. Cell 2012, 23, 1238-1246. [CrossRef] [PubMed] 